\title{
Küresel Tedarik Zinciri ve Uluslararası Ticaret Yönetiminde Verimli Ödeme Sistemi Seçimi
}

\author{
Işılay TALAY ${ }^{1}$ \\ Orkun BAYRAM ${ }^{2}$
}

\begin{tabular}{ccc}
\hline $\begin{array}{c}\text { Geliş Tarihi/ Received } \\
\text { 16/03/2020 }\end{array}$ & Kabul Tarihi/ Accepted & Yayın Tarihi/ Published \\
$02 / 06 / 2020$ & $15 / 07 / 2020$ \\
\hline Citation/Atıf: Talay, I. ve Bayram, O., (2020), Küresel Tedarik Zinciri ve Uluslararast Ticaret \\
Yönetiminde Verimli Ödeme Sistemi Seçimi, Atatürk Üniversitesi İktisadi ve İdari Bilimler \\
Dergisi, 34(3): 945-972, DOI: 10.16951/atauniiibd.704616 \\
\hline
\end{tabular}

Öz: Bu çalışmada küresel tedarik zincirinde fon akıșı için gerekli uluslararası ödemeleri gerçekleştirmek amacıyla kullanılabilecek iki ödeme sistemi olan SWIFT ağı ve blok zincir ağ tabanlı ödeme sistemlerinden hangisinin hangi koşullar altında seçilmesi gerektiği ile karar mekanizması matematiksel modelleme yoluyla incelenmiştir. Tedarik zincirlerinde ürün akışının yanında bilgi ve fon akışını da koordine edebilmek büyük önem taşımaktadır. Tüm akışların gecikmeden ve sorunsuz yürütülmesi ile küresel tedarik zinciri ve uluslararası ticaretin yönetiminde yüksek performans elde edilebilir. Bu çalışmada fon akışının zamanında ve sıkıntısız gerçekleştirilmesi için verimli ödeme sistemi seçimi kararı incelenmiştir. Modelde, bu iki ödeme sistemine ait dinamikler, olasılık dağılımları ve diğer parametreler vasıtasıyla ifade edilmiştir. SWIFT ve blok zincir ağı ödeme sistemleri arasında, bu sistemlerin gönderici için olușturacakları toplam maliyetlerin stokastik kıyaslaması yapılmıştır. Blok zincir ağının, sunduğu maliyet avantajını koruyarak, her durumda SWIFT'e tercih edilebilir olabilmesi için ödemenin başarılı olma ve aynı gün içerisinde tamamlanma ihtimalini SWIFT'ten daha yükseğe çıkarması, ayrıca ödemenin başarısız olması durumunda da ödeme miktarını tazmin etmesi gerekmektedir. Bu sayede riske duyarsız bir göndericinin istikrarlı olarak SWIFT yerine blok zincir ağını tercih etmesi mümkün olabilir, riskten sakınan bir gönderici ise ilk olarak iki sistem arasındaki komisyon yüzdesi farkı ile blok zincir ağındaki ödeme kaybı olasılığını kıyaslayacaktır.

Anahtar Kelimeler: Küresel Tedarik Zincirleri, Uluslararası Ticaret, SWIFT, Blok Zincir Ağı, Ödeme Sistemi

\section{Efficient Payment System Selection in Global Supply Chains and International Trade Management}

Abstract: In this study, whether to make a cross-border payment in a global supply chain with SWIFT or block chain has been established via mathematical modeling. It is extremely important in supply chains to coordinate information and funds flow as well as physical flow of goods. It will be possible to achieve high performance in a global supply chain and international trade via timely and smooth execution of all flows. In this study we investigated the choice of the cross-border payment system to accomplish supply chain funds flow, and the stochastic comparison

${ }^{1}$ Dr. Öğr. Üyesi., Antalya Bilim Üniversitesi, İktisadi, İdari ve Sosyal Bilimler Fakültesi, Isşletme Bölümü, https://orcid.org/0000-0002-8956-9505

${ }^{2}$ Dr. Ögr Bölümü, https://orcid.org/0000-0001-9958-7822 
Küresel Tedarik Zinciri ve Uluslararası Ticaret Yönetiminde Verimli Ödeme Sistemi Seçimi

of total costs of these systems was conducted. In order for the block chain network to be preferable to SWIFT in all cases, while maintaining the cost advantage it offers, it should increase the probability of the payment being successful and completed within the same day than SWIFT, and also compensate the amount of payment in case the payment is unsuccessful. In this way, it may be possible for a risk-insensitive sender to choose the block chain network instead of SWIFT, while a risk-avoiding sender will first compare the commission percentage difference between the two systems and the possibility of payment loss in the block chain network.

Keywords: Global Supply Chains, International Trade, SWIFT, Block Chain Network, Payment System

\section{Research Problem}

The purpose of the study was to explore the payment system selection in global supply chains and international trade. The choice is considered to be between the SWIFT and the block chain network based on stochastic comparison of total costs and risks for each system.

\section{Research Questions}

What are the factors affecting the cross-border payment system selection?

What are the relative advantages and disadvantages of SWIFT and block chain network based cross-border payment systems?

What are the uncertainties governing the process of cross-border payment?

How could we analyze the choice between SWIFT network and blockchain oriented cross-border payment options concerning the uncertainties inherent in either system?

\section{Literature Review}

The purpose of the literature review was to present the current status of two main cross-border payment systems in use, namely SWIFT and block chain networks. The researchers reviewed the literature from three main aspects: the use of SWIFT network for cross-border payments, the use of block chain network for cross-border payments, and the comparison of these two systems. While the advantages and disadvantages of these systems has been studied in the literature, there has been no attempts yet to analyze a decision mechanism taking into account uncertainties inherent in the cross-border payment process.

\section{Methodology}

In this study, the decision problem faced by the sender for a cross-border payment is represented as the probabilistic / stochastic comparison of two random variables representing the total costs / losses that the payment systems bring. The random variables representing the total costs and risks of these two systems are derived first, and then these random variables and their probability distributions were analyzed via the first and second order stochastic dominance criteria. Examples were provided to demonstrate the principles derived and also present implications for the administration of two systems.

\section{Results and Conclusions}

It was found that the main advantages of the SWIFT network were the high level of established standards and procedures governing the regulations for this 
network. Thanks to these establishments, the risk of losing the payment amount is negligible for the sender. However, this risk is not negligible for block chain networks. Meanwhile, the processing times are longer for the SWIFT network since this network does not conduct the financial bookkeeping and it only relays messages between the institutions. The longer processing times create indirect costs due to time value of money and exchange rate fluctuations. The uncertainties in the model stem from the uncertainties in SWIFT's payment processing times, volatilities on exchange rates, and the risk of payment failure and loss in the block chain system.

In the model, dynamics of these two payment systems are specified as random variables and parameters, and in order to reveal the decision mechanism, stochastic comparison of the costs of the two payment systems for the same payment was made. The desirability of the blockchain network compared to the SWIFT system has a strong relationship with the risk of failure in cross-border payment with the blockchain and the sender losing the payment amount. Despite the fee and speed advantage offered by cross-border payment with the blockchain network, in order for this payment system to be preferred instead of SWIFT, the possibility of payment loss must be eliminated or at least the amount of the failed payment must be returned to the sender. In order for the block chain network to be preferable to SWIFT in all cases, while maintaining the cost advantage it offers, it should increase the probability of the payment being successful and completed within the same day than SWIFT, and also compensate the amount of payment in case the payment is unsuccessful. In this way, it may be possible for a risk-insensitive sender to choose the block chain network instead of SWIFT, while a risk-avoiding sender will first compare the commission percentage difference between the two systems and the possibility of payment loss in the block chain network. Therefore, blockchain network payment system administrators must ensure the security of transactions at all stages of payment, from transactions in the crypto currency wallet of the sender to the receiver's account, and compensate the amount of payment in case of processing failure even if it is not a legal obligation.

\section{Giriş}

Küresel tedarik zinciri, bir işletmenin, bulunduğu ülke dişından ürün ve/veya hizmet temin edebilmesi amacıyla dünya çapında oluşturulan bir ağ yapısıdır (Chartered Institute of Procurement \& Supply, t.y.). Bu ă̆ yapısı ile gerekli teminlerin yapılabilmesi için ürün, hizmet, bilgi ve para akışları yürütülür. Küresel tedarik zinciri içerisinde faaliyet göstermenin işletmelere sunduğu pek çok olanak bulunmakla birlikte oluşturduğu riskler de söz konusudur. Bu risk kategorilerinden birisi de nakit akışlarında yaşanabilecek aksaklıklarla ilgilidir.

Küresel tedarik zincirinde farklı ülkelerde bulunan işletmeler arasında, ödemeler suretiyle nakit akışları olacaktır, ancak sınır ötesi veya uluslararası 
Küresel Tedarik Zinciri ve Uluslararası Ticaret Yönetiminde Verimli Ödeme Sistemi Seçimi

ödemelerde gecikme yaşanması durumunda işletmelerin nakit yönetimi veya döviz kurlarında yaşanabilecek dalgalanmalardan (Moslemi vd., 2016: 260) dolayı sıkıntı yaşaması mümkündür (Manuj ve Mentzer, 2008a: 143; Manuj ve Mentzer, 2008b: 199). Ödemelerde gecikmenin yol açabileceği risklerin yanında ödeme sisteminin etkin çalışmamasından veya verilerini koruyamamasından ve gerekli hukuksal destek yapısının da olmamasından ötürü ödemenin teyit edilememesi (Curkovic vd., 2013: 25; Scannell vd., 2013: 373) sebebiyle para kaybı da söz konusu olabilir. Küresel tedarik zinciri içerisinde faaliyet gösteren işletmelerin uluslararası ticaret yaparken maruz kaldığ1 sınır-ötesi ödemelerle ilgili bu riskler sebebiyle, sınır-ötesi ödemeleri güvenli, hatasız, eksiksiz ve hızlı yapabilmek önemli bir ihtiyaç haline gelmiştir.

Uluslararası ticarette sınır-ötesi ödemelerin sorunsuz gerçekleştirilmesi ihtiyacına cevap vermek için bu konuda uzmanlaşmış kurumlar ortaya çıkmış ve mevcut uluslararası ticaret ortamında farklı ödeme sistemleri işletmelerin seçimine sunulmuştur. Günümüzde kullanılmakta olan uluslararası ödeme sistemlerinden en yaygın ve standartlaşmış olanı SWIFT (Society for Worldwide Interbank Financial Telecommunications) ağıdır. SWIFT ağı ile her gün bu ağa üye olan 10.000'den fazla finansal kurum 24 milyondan fazla uluslararası ödeme talimatı vermektedir (Mohanty, 2019: 26). SWIFT ağına üye olan finansal kurumlar arasında bankalar, yatırım firmaları ve diğer finansal işlem hizmeti veren firmalar bulunmaktadır. SWIFT ağı uluslararası ödeme talimatlarının güvenli ve hatasız bir şekilde ağa üye kuruluşlar arasında iletilmesini sağlamak için SWIFT'e özgü standart ödeme talimatı kodlarını oluşturmuştur ve umumi internet hatlarını değil, kendi bünyesinde güvenliği sağlanmış hatları kullanmaktadır (EXALOG - Payments \& treasury software, t.y. a). SWIFT ağı, üyelerine sınır-ötesi ödemeler için güvenli ve hatasız iletişimin yanında, işlemleri tamamlamak için gerekli ara yüz sağlama hizmetini de sunmaktadır. Bu sayede, finansal kurumlar, hizmet talep edilen bir uluslararası ödeme işlemi için öncelikle işlem bilgilerini SWIFT sayesinde paylaşmakta, daha sonrasında ise SWIFT ağı tarafından sağlanan ara yüz ile işlemi tamamlamaktadır (Park, 2007: 27).

Uluslararası ödeme sistemi olarak son yıllarda blok zinciri ağ yapısından da faydalanılmaya başlanmıştır. Blok zinciri ağ yapısı, kriptografi (şifreleme bilimi) yöntemleriyle tüm ağ üyeleri arasında gerçekleştirilen işlemlere ait bilgilerin, sonradan değiştirilemez ve tüm üyeler tarafından doğrulanacak şekilde ağa üye olan kişi ve/veya kurumlar tarafindan saklanmasını sağlamaktadır (Narayanan vd., 2016; 21). Blok zinciri ağ yapısı pek çok farklı işlem türüne ait bilgilerin yürütülmesi, teyidi ve güvenli veri depolaması için kullanılmaktadır, bu kullanım alanlarından birisi de uluslararası ödeme sistemleridir. Blok zinciri ağ yapıs1 ilk kripto para birimi olan Bitcoin'in dolaşımının, merkezi bir otorite tarafindan teyide gerek kalmadan otonom bir şekilde tüm ağ üyeleri ile verilerin paylaşılarak sağlanması için bulunmuştur (Nakamoto, 2019). Bitcoin aktif olarak dolaşıma başladıktan ve blok zinciri ağ yapısı kitleler tarafından incelendikten sonra bu protokolün kripto paraların dolaşımı dışında pek çok kullanım alanı 
olabileceğinin farkına varılmıştır. Bu kullanım alanlarından birisi de uluslararası bankacılıktır. Blok zinciri ağ yapısının merkeziyetçi olmayan yapısı, dağıtık hesap defteri (distribured ledger) olarak adlandırılmış, dağıtık hesap defterinin uluslararası para akışında kullanılması konusunda gerekli ticari düzenlemelerin oluşturulması için de çalışmalara başlanmıştır (Cheng ve Geva, 2016: 1). Blok zincir ağ yapısının SWIFT ağ yapısından en büyük farkı ödeme talimatı iletimi ile para akışının eş zamanlı olarak yapılabilmesidir. SWIFT ağında öncelikle ödeme talimatının her işlem aşamasını temsil eden finansal kurumlarda ayrı ayrı teyidi yapılmaktadır, tüm teyit işlemleri bittikten sonra ödeme işleminde yer alacak kurumlar tarafından hesaplardaki fon eksiltme/arttırma işlemleri tamamlanmak suretiyle ödeme gerçekleştirilmektedir. Ancak blok zinciri ile gerçekleştirilen ödemelerde ödeme talimatı ve fon işlemlerinin ağ üyeleri arasında eş zamanlı ve daha az adım içerecek şekilde gerçekleştirilmesi mümkündür (Wu ve Liang, 2017: 221).

Küresel tedarik zincirinde faaliyet gösteren bir işletme için uluslararası ödeme yapma ihtiyacı duyulduğunda SWIFT veya blok zinciri tabanlı bir ödeme sistemi tercih edilebilir. Blok zinciri tabanlı ödeme sistemleri arasında en yaygın olarak kullanılanlardan birisi ise Ripple'dır (Wu ve Duan, 2019: 3). Ripple ile sadece ödemenin gerçekleştiği finansal kurumlar arasında bir mesaj trafiği koordine edilmemekte, ayrıca, ödeme miktarı ilgili kurumların hesaplarına da işlenmektedir. Bunun için Ripple ağı üzerinde her bankanın hesap ve işlem bilgisinin saklandığı bir sanal defter tutulmaktadır. Farklı para birimleri arasında da işlem yapılabilmekte ve saniyelerle ölçülebilecek şekilde ödemeler tamamlanabilmektedir. Ayrıca işlemlerin ya gerçekleştirilmesinin hiç kabul edilmemesi ya da kesin olarak gerçekleştirilmesini sağlayan bir kontrol mekanizması da bulunmaktadır. SWIFT ağı ise uzun yıllardır faaliyet göstermektedir ve tüm dünya çapında oldukça yaygınlaşmış bir üye platformu bulunmaktadır, ancak blok zinciri tabanlı ödeme sistemleri de oldukça yeni kullanıma açılan bir platform türü olmasına rağmen üye sayılarını arttırmaktadırlar (Guo ve Liang, 2016: 6). Farklı uluslararası ödeme sistemlerinin varlığında, işletmeler için, ihtiyaç duyulan ödeme hizmetinin karakteristiklerine göre hangi ödeme sisteminin seçileceği kararı önem kazanmaktadır. Farklı ödeme sistemlerinin farklı özellikleri, avantajları ve dezavantajları söz konusudur. Dolasıyla farklı koşullarda farklı bir ödeme sisteminin seçimi söz konusu olabilir.

$\mathrm{Bu}$ araştırmanın amacı küresel bir tedarik zinciri üye işletmeleri arasında yapılması planlanan uluslararası bir ödeme için SWIFT sistemi ile blok zinciri tabanlı ödeme sistemlerinden hangisinin seçilmesi gerektiği ile ilgili karar mekanizması inceleyen bir matematiksel model ve bu seçimi etkileyen faktörleri ortaya koymaktır. Blok zinciri tabanlı sınır-ötesi ödemelerin yeni yeni yaygınlaşmakta olması sebebiyle yazarların bilgisi dâhilinde henüz iki ödeme sisteminin kıyaslamasını ortaya koyan bir matematiksel model oluşturulmamıştır ve bu çalışma, bu alanda gerçekleştirilen ilk çaba olmayı hedeflemektedir. 
Küresel Tedarik Zinciri ve Uluslararası Ticaret Yönetiminde Verimli Ödeme Sistemi Seçimi

\section{Literatür Taraması}

Bir ticari işlemden dolayı alıcı tarafından satıcıya ödeme yapılması gerektiğinde çoğu zaman ticaretteki taraflar bankalar veya diğer finansal kurumların aracılığına ihtiyaç duymaktadır. Ödemenin sonunda istenen sonuç ise alıcıya ait finansal hesaptan ödeme miktarının düşülmüş, satıcıya ait finansal hesaba ise ödeme miktarının eklenmiş olmasıdır. Bu işlemlerin de alıcıyı temsil eden finansal kurum tarafindan satıcıyı temsil eden finansal kuruma fon akışı şeklinde gerçekleşmesi beklenir. Ancak bu fon akışının en hızlı şekilde gerçekleşmesi için alıcıyı temsil eden finansal kurum ile satıcıyı temsil eden finansal kurumun da karşılıklı olarak birbirlerinde diğer tarafa ait hesaplarının olması gerekmektedir. Dolayısıyla kurumların da birbirlerine ait hesaplarda ödemeye ilişkin fon akımını gerçekleştirmesi gerekmektedir. Küresel tedarik zincirlerinde alıcı ve satıcının aynı ülkede ticari faaliyet göstermediği durumlarda alıcıyı ve satıcıyı temsil eden finansal kurumların bu tür bir hesap ilişkisi çoğunlukla olmamakta ve iki kurum arasında hesaplardan fon aktarımı için aracı olacak diğer finansal kurumlara ihtiyaç duyulmaktadır. Bu kurumların tespiti ve ödemeye dâhil edilecek tüm finansal kurum ve kuruluşlar arasında güvenli iletişimin sağlanması uluslararası ticarette fon akışının sorunsuz gerçekleşmesi için büyük önem teşkil etmektedir. Sınır-ötesi ödemeler için finansal kurumlar arasında gerekli iletişim ve işlemlerin tamamlanması amacına yönelik çözüm ihtiyacı küresel tedarik zincirlerinin ortaya çıkmasından itibaren hissedilmiştir. Önceleri telegraf ve sonrasinda Telex sistemi ile bu ihtiyaca cevap verilmeye çalışılmış, ancak farklı kurumların farklı işlem veya hesap tutma sistemlerinin olması ve ayrıca mesajların İngilizce düz metin olarak yazılıyor olması pek çok karışıklığa ve hatalara yol açmıştır (Scott and Zachariadis, 2012; 465). Uluslararası ticarette karşılaşılan ödeme zorluk ve ihtiyaçlarına Telex sisteminin cevap verememesi sonucu 1960'lı y1llardan itibaren farklı ülkelerden finansal kurumların bir araya gelmesi ile bu soruna bir çözüm üretecek bir girişim olarak SWIFT, 3 Mayis 1973'te kurulmuştur (Scott and Zachariadis, 2012; 466).

\subsection{Uluslararası Ticarette SWIFT A $\breve{g l}$ ile Ödeme Sistemi}

SWIFT, kar amacı gütmeyen bir finansal kurumdur, bir banka ya da hesap düzenleyici bir kurum ise değildir ve müşterilerine ait hesapların yönetimini de üstlenmemektedir. SWIFT sisteminin amacı uluslararası ödemelerde işlemlerle ilgili detayların güvenli ve hataya yer bırakmadan ilgili kurumlar arasında iletilmesini sağlamaktır. Dolayısıyla SWIFT finansal işlemlere ait verilerin düzenlenmesi ve dağıtımına odaklanmış, verileri ileten ancak depolamayan bir ağ yapısıdır. Ağ üyesi kuruluşlar arasında iletişim kurulması ve finansal bilgilerin güvenilirlik, gizlilik ve doğruluk ilkeleri altında paylaşılması için gerekli platform, ürün ve hizmetleri sağlar. Başlangıçta az sayıda bankaların kendi aralarında ödeme işlemlerinin sorunsuz yürütülmesi için kurulmuş olan SWIFT günümüzde uluslararası ticarette sınır-ötesi ödemeler için bir norm ve tüm 
dünyadaki binlerce finansal kurumu bünyesinde bulunduran bir ağ haline gelmiştir (Scott ve Zachariadis, 2012: 462).

Uluslararası boyuttaki finansal işlemler telgraf ve kablo teknolojisinin temelleri atıldıktan sonra başlamıştı ve 20. yüzyılın başında farklı kıtalardaki bankalar muhabir bankalar aracılı̆̆ı ile ödeme faaliyetlerini gerçekleştirmekteydi (Batiz-Lazo ve Wood, 2002: 193-194). 1950'li yıllarda ise kitalar arası finansal kurumlar mevcut telefon ve telgraf hatlarını kullanarak konuşma ve yazı sinyallerini ileten Telex sistemi sayesinde birbirleri ile iletişim kurmaktaydılar. Bu esnada pek çok büyük ölçekli Amerikan ve İngiliz bankaları da elektronik veri işleme ile ilgili büyük bütçeli yatırımlar yapmaya başlamışlardı, bu sayede Amerika ve İngiltere'de elektronik fon transferi sistemleri geliştirilebildi. 1970'li yıllara gelindiğinde ise veri işlemede verimliliği sağlayan ve uluslararası işlem kapasitesini genişleten bankaların küresel finansta büyük söz sahibi olmaya başladığı gözlendi. Öyle ki Amerika dışındaki firmalara verilen kredilerin \%67'si sadece on iki uluslararası banka tarafından sağlanmaktaydı. Bu ölçekte işlem yapan bankalar faaliyetlerini sürdürdükçe güvenilir bir şekilde iletişim sağlayan bilgisayar destekli sistemlere olan ihtiyaç arttı (Scott ve Zachariadis, 2012: 464465).

Küresel tedarik zincirlerinin kapsama alanı arttıkça bu zincirlerde yer alan firmalarla uluslararası bankalar arasındaki işbirlikleri de arttı. Sınır-ötesi ödemeler için bankalar ve kurumlar arasında elektronik veri değişimi sistemleri oluşturuldu. $\mathrm{Bu}$ işlemler için kamuya açık hatların kullanılması istenmiyordu çünkü zaten yoğun trafiğge sahip olan bu hatların bankaların işlem hacimleri büyüdükçe bir kısıt oluşturacağı bilinmekteydi. Büyük ölçekli işlem yapan bankalar kamu hatları yerine Posta, Telefon ve Telgraf idaresinden devre ve uydu tabanlı özel hatlar kiralayarak kendi iletişim ağlarını oluşturmaya başlamışlardı. $\mathrm{Bu}$ şekilde davranmalarının bir başka sebebi de iletişimle ilgili kendi güvenlik standartlarını koruyabilmekti. Ayrıca ödemelerle ilgili işlemlere ait mesajlara bir standart getirilmesi de istenmekteydi. Citibank bununla ilgili ilk adımı atmış, ancak endüstri bu standardın tek bir banka tekelinde kalmasına karşı çıkmıştı. Sonunda bu anlaşmazlıklara ancak bir araya gelinerek bir çözüm getirilebileceği kanaatine var1ld1 (Scott ve Zachariadis, 2012: 464-465).

1971 yılına gelindiğinde Batı Avrupa ve Kuzey Amerika'daki 11 ülkeye ait 68 banka tarafından, hususi ve uluslararası bir iletişim ağının kurulabilir olup olmadığını araştırmak üzere iki ayrı danışmanlık projesinin sponsorluğu üstlenildi. $\mathrm{Bu}$ projelerden birisi teknik ve finansal açıdan, diğeri ise organizasyonel ve yasal açıdan yapılabilirliği ölçtü. Projelerden olumlu bir yargı ortaya çıkınca dâhil olan her ülkeden temsilcilerin katkısıyla sınır-ötesi ödemelere ilişkin mesajlaşmalar için standartlar oluşturuldu ve 3 Mayıs 1973'te SWIFT, finansal kurumlar arasında kar amacı gütmeyen bir işbirliği olarak kuruldu. Kuruluşu esnasında 15 ülkeden 239 banka bu ağa üye olmuştu. 1974 yılının sonuna gelindiğinde ağ yapısının tasarımı tamamlanmış ve donanım ve yazılımı sağlayacak firma ile anlaşmaya varılmıştı. 1979 yılına gelindiğinde ise 
Küresel Tedarik Zinciri ve Uluslararası Ticaret Yönetiminde Verimli Ödeme Sistemi Seçimi

sistem üzerinde günlük 120.000 mesaj iletilmekteydi. SWIFT sisteminin getirdiği Telex sistemine kıyasla getirdiği en önemli faydalar arasında işlemlerin hızlanması, maliyetlerin düşmesi, işlem hacminin ve güvenliğinin artması ve mesajların standart bir yapıya sahip olarak anlaşılabilirliğinin arttırılması sayılabilir. İşlemlerin hızlanması ile mesajların güvenilirliğinin teyidinin daha az zaman alması, maliyetlerde azalma ile de diğer mesaj iletme yollarına göre ücretin beş kat daha düşük olması ve daha az işgücüne ihtiyaç duyulması sağlanmıştır. Sistemdeki mesajlaşma yapısının net, özgün, kısa ve pratik olması sayesinde bankalar bu mesaj sistemini kendi iç işlerinde de uygulamaya başlamışlardır (Kozolchyk, 1992: 42).

SWIFT sınır-ötesi ödemeler için gerekli talimatların verilmesinde belirli bir standardın oluşmasını sağlamıştır, bir finansal kurum için SWIFT sisteminden gelen bir ödeme talimatı kurumun işlemleri yapabilmesi için gerekli güveni sağlamaktadır (Ivannikov vd., 2014: 47). Dolayısıyla SWIFT'in finans piyasalarına kattığı değer finansal varlıkların transferinin yapılması değil finansal aktörler arasında güvenli bağlantıların kurulabilmesidir. Bu özelliğinden dolayı SWIFT'in yapılanmasındaki zaman içindeki genişlemeler ulusal takas sistemleri, kambiyo sistemleri ve Euro tahvil sistemlerini hedeflemiş ve bağlantı kurulan finansal işlemlerin kapsama alanı genişletilerek finansal işlem sürecinin başından sonuna değin güvenli bağlantıların paydaşlara sunulması sağlanmıştır. $\mathrm{Bu}$ avantajlar sayesinde ise SWIFT ağının üye sayısı gittikçe artmış ve bu da sunulan avantajların etkisini daha da arttırmıştır. SWIFT ağını oluşturan topluluk Brüksel merkezli ve Belçika kanunlarına tabi olarak kurulmuştur. Belçika'nın sunduğu yasal ve finansal avantajlardan dolayı bu şekilde bir seçim yapılmıştır. Bununla beraber SWIFT sistemi işletilmeye başlandıktan sonra uluslararası finansal işlemler için ortak bir yasal yapının eksikliği ortaya çıkmış ve SWIFT sisteminin işletim prensipleri bu açığı kapatacak yeterliliğe sahip bulunmamıştır. Finansal kaynakların transferi işleminde yer alan tüm tarafların sorumluluk ve haklarını belirten bir kanun yapısına ihtiyaç duyulmuştur. Özellikle ödemedeki gecikmelerden kaynaklanan faiz geliri kaybının karşılanmasına ilişkin çıkan sorunlara cevap olarak Şubat 1979 'da SWIFT ağına üye kuruluşlar ortak bir kurallar bütününü benimsemiştir. $\mathrm{Bu}$ kurallar anlaşmazlık durumunda uygulanacak kanunları, sorumlulukları, karşılanacak olan zararın tutarını ve ödemelerin zamanlana ve süresine ilişkin ölçütleri içermektedir (Ambrosia, 1980: 314). Dolayısıyla SWIFT sisteminde yaşanabilecek aksaklıklar ile ilgili sınırötesi ödemenin göndericisi ve alıcısını koruyacak bir kurallar bütünü ortaya koyulabilmiştir ve SWIFT sistemi uzun yıllar boyunca sınır-ötesi ödemeler için tüm dünyada kullanılan başlıca ödeme sistemi olmuştur. Ancak zaman geçtikçe küresel finansal tedarik zincirleri de gelişmiş ve SWIFT sisteminin, üyelerinin ihtiyaçlarına hız ve maliyet açısından yeterince cevap veremediği durumlar ortaya çıkmıştır. İdari ve teknolojik gelişmişlik açısından da SWIFT sistemi sürekli olarak incelenmeye ve değerlendirilmeye devam etmektedir. 
Uluslararası ticarette alıc1 ve satıcıyı temsil eden finansal kurumların birbirlerinde karşılıklı hesapları olmadığı zaman aracı olmak durumunda kalan ne kadar çok kurum var ise iletilmesi gereken mesaj sayısı da o derece artmaktadır. SWIFT sistemine üye olan ve ödemenin taraflarını temsil eden finansal kurumlar birbirlerine ait hesapları tutmuyor iseler muhabir bankalar aracılığıyla işlemleri gerçekleştirmek durumundadırlar. Tek bir muhabir bankayı içeren bir sınır-ötesi SWIFT ödeme işlemi ele alınacak olursa parayı gönderen taraf onu temsil eden bankaya gerekli talimatı verdikten sonra göndericiyi temsil eden banka kendi terminalinden mesaj1 mesaj toplama merkezine iletmekte, mesaj toplama merkezinde kümelenen mesajlar ise mesaj iletim merkezine yönlendirilmektedir. Mesaj toplama merkezleri ve mesaj iletim merkezi arasındaki bağlantı SWIFT tarafindan hususi olarak sahip olunan hatlarla yapılmakta ve bu da güvenlik ve işlem hızını arttırmaktadır. Mesajın içeriğinde mesajın öncelik sırasını belirleyici numara, ödemenin alıcısının isim ve adres gibi bilgileri, ödeme miktarı, muhabir bankanın ödeme miktarının kullanım hakkını elde edeceği tarih, muhabir bankanın alıcıyı temsil eden bankaya ödemeyi ileterek alıcının ödemeyi teslim almasının sağlanacağı tarih bilgileri bulunur. Tek bir muhabir banka söz konusu olduğunda bile çok aşamalı olan bu işlem sürecinde gecikmelerden dolayı faiz getirisi kayıplarının yaşandığı durumlar tecrübe edilmiş ve bu kayıpların sorumluluğu ile ilgili yükümlülükler tartışma konusu olmuştur. Şubat 1979'da kabul edilen prosedürler çerçevesinde, gönderici bankanın, SWIFT ağının, muhabir bankaların ve alıcı bankanın sorumlu tutulacağı durumlar ve faiz kaybının karşılanması ile ilgili yapılacak ödemelerin miktarına ilişkin hususlar belirlenmiş̧ir (Ambrosia, 1980: 314). Dolayısıyla SWIFT sisteminde ödemenin iletilmesi ve ödemedeki gecikmelerden kaynaklanan faiz kaybı ile ilgili, ödemeyi yapan ve alıcı açısından riskler bulunmamaktadır, çünkü ödemenin taraflarını temsil eden finansal kuruluşlar ve SWIFT bu konuda sistemsel düzenlemeleri gerçekleştirmiştir.

SWIFT sistemindeki riskler ve bunlardan doğabilecek sorumluluklar ile ilgili oluşturulmuş prosedürlerin kapsamlı olarak içermediği sorunlar arasında, ödemede gecikme olduğunda ödemeyi yapan taraf ile alıcının tabi olduğu para birimleri arasındaki döviz kurunda yaşanan dalgalanmalardan dolayı alıcının kaybı olursa sorumluluğun kime ait olacağının tam olarak kesinleştirilmemesi yer almaktadır. Kayıplar yüksek olursa alıcı veya gönderici çalıştıkları finansal kurumlardan yasal yollarla hakkını aramak durumunda kalacak ve belirli mağduriyetleri olacaktır. Ancak savaş, grev, sabotaj gibi dış etkenler veya güvenlik açıkları gibi sebeplerden paranın alıcıya ulaşmaması durumunda ödemeye dâhil olan finansal kuruluşlar veya SWIFT ödemeyi karşılayacaktır. Ödeme eninde sonunda mutlaka gerçekleşecektir gecikmelerle de olsa ve SWIFT ağındaki üye finansal kuruluşlardan bu gibi durumlara karşı gerekli sigortalama işlemlerini yapmaları beklenir (Ambrosia, 1980: 325-327).

İşlem bilgilerini içeren mesajlar ne kadar standartlaştırılmış ve kurumlara özgü iş yapma tarzı veya kullanılan lisanın farklılığı bariyerlerinden ne kadar 
Küresel Tedarik Zinciri ve Uluslararası Ticaret Yönetiminde Verimli Ödeme Sistemi Seçimi

arındırılmış olursa hata oranı da o derece azalacak ve mümkünse tamamen yok edilmesi mümkün olabilecektir. Standartlaşmanın yanında, mesajların veri güvenliği sağlanmış bir şekilde iletilmesi de önem taşımaktadır, SWIFT ağı gerekli güvenlik ihtiyaçlarına cevap verebilmek için kendisine ait IP ağına sahiptir ve ödeme talimatları üye kurumlar arasında bu hatlar yoluyla iletilmektedir. Standartlaşma ve güvenli altyapı ile iletişim hizmeti sunması SWIFT ağını uluslararası ödemelerin yapılması için bir norm haline getirmiştir. SWIFT günümüzde bir günde 24 milyon civarında mesajın iletimini yapmaktadır. $\mathrm{Bu}$ şekilde bir işlem hacmine sahip olan bir başka sınır-ötesi ödeme ağı daha bulunmamaktadır. SWIFT ağı ile yapılan ödemelerde ödemeyi gönderenin ve alıcının üstlendiği maliyetler ve risklere bakıldığında ise, işlem maliyetleri ödemeyi yapacak kişiye en baştan belirtilmekte, ancak ödemede gecikme ve bu esnada döviz kurlarında dalgalanmalar olursa bundan doğacak mağduriyetler ödemeyi yapan kişi ve alıcı açısından bir risk oluşturmaktadır. Bilgi işlem teknolojisi ilerledikçe finansal odaklı bilgi işletim sistemlerinde de büyük ilerlemeler görülmüştür ve SWIFT ağının mevcut yapısı ile vermekte olduğu hizmete kıyasla çeşitli avantajlar sunan blok zinciri odaklı uluslararası ödeme sistemleri de uluslararası ticarette varlığını göstermeye başlamıştır. SWIFT ağı hizmet taleplerine daha iyi cevap verebilmek için 2017 y1lında Global Payment Innovation Initiative (GPI) başlığı altında sisteminde köklü yeniliklere gitmiş ve ayrıca blok zincir yapısı ile sistemini işletebilmek için 34 banka ile bir deneme sürümü gerçekleştirmiştir (Casey vd., 2018: 19). Mevcut durumda SWIFT GPI yapısından faydalanabilen finans kurumlarında gerçekleştirilen sınır-ötesi ödemelerin \%50'si 30 dakika içerisinde, \%100'ü ise 24 saat içerisinde tamamlanmaktadır. Standart sınır ötesi ödemelerin aldığı süre ise 3-5 gün arasindadır (EXALOG - Payments \& treasury software, t. y. b).

\subsection{Uluslararası Ticarette Blok Zincir Ağı ile Ödeme Sistemi}

Blok zinciri ağ yapısı, ilk kripto para birimi olan Bitcoin'in dağıtımı için geliştirilmiştir. Merkez Bankası veya benzeri merkezi otoriteyi temsil eden kurumlara gerek kalmadan, kripto para birimlerinin dolaşımını listeleyen işlemler dizininin, birbirleri ile öncelik sırasına göre ve belli şifre yapıları ile ilişkilendirilen bilgi blokları halinde, ağ üyeleri arasında güvenli, hatasız ve eksiksiz bir şekilde paylaşımını sağlayan şifreleme prosedürleri dizinidir (Underwood, 2016: 15). Bitcoin'i, büyük ölçekli finans kurumları ve bankalar arasında sınır-ötesi ödemeler için altına benzer bir araç olarak değerlendirmek de mümkün görülmektedir. Bu düşüncedeki ana amaç tüm dünyada geçerli olan bir para biriminin ele alınması ve altından farklı olarak da taşınması veya aktarılmasının dijital ortamda yapılabilmesidir. Bu şekilde sınır-ötesi ödemelerde döviz kurlarındaki dalgalanmalar ve benzeri problemleri de bertaraf etmek mümkün olabilir. Ancak Bitcoin ve altyapısını oluşturan blok zincir ağ yapısında gerekli şifreleme bilimi (kriptografi) hesaplamalarının yapılabilmesi için her işlem başına yaklaşık $244 \mathrm{KWh}$ enerji harcaması gerekmektedir. Bu enerji 
ABD'de sekiz hanenin günlük enerji tüketimine karş1lık gelmektedir. Bu boyutta bir enerji tüketimi kişisel ödemelerin gerektirdiği işlem hacmini karşılayamayacaktır, fakat belirli ölçekteki kurumlar arasında gerçekleştirilebilecek, hacim olarak az ama miktar olarak toplu yapılacak ödemeler için gerçekleştirilmesi olası kabul edilebilir. Dolayısıyla blok zincir ağ yapısı da SWIFT sistemi gibi finansal kurumların üye olabileceği bir platform oluşturarak sınır-ötesi ödemelerin gerçekleştirilmesini sağlayabilir (Sivitska, 2018: 49). Teoride mümkün görünen bu ihtimal pratikte değerlendirildiğinde ise kripto paralar için kullanılan blok zincir ağ yapısının gizlilik, maliyet kontrolü, işlem hacmi, kurumlar arası rekabet ortamı sağlama, yasal düzenlemeler gibi açılardan çeşitli sektörlerin ihtiyaçlarına cevap vermekte zorlandığına değinilmektedir. Bu gözlemden dolayı sınır-ötesi ödemeler için Ripple gibi daha farklı blok zincir ağ yapıları geliştirilmiştir (Vanetti, 2018: 3).

İşlemler için talimatlar geldikçe, yeterli miktarda işlem bilgisi oluştuğunda bu bilgilerin bir blok yapısı ile blok zincir ağ yapısı ilk oluşturulduğundan bu yana tutulan bloklar halindeki ve birbirine şifreleme yöntemleri ile bağlanmış bilgi dizinine eklenmesi gerekmektedir. Bu eklemenin tüm ağ üyeleri tarafindan teyit edilmesi ile işlemler onanmış olmaktadır. Blok zincirine yeni blok eklemek ve işlem tarihçesini ilerletmek için bu yetkiye sahip olmak isteyen ağ üyeleri tarafından matematiksel bir bulmacanın bilgi işlem kapasitesi ile çözülmesi gerekmektedir. Bunu yapabilmek için bilgi işletim sistemini destekleyecek enerjinin de sağlanmasına ihtiyaç duyulmaktadır. Bu ihtiyaçları karşılayarak gerekli çözümü bulan ağ üyelerinin bu başarısı, diğer ağ üyeleri tarafından teyit edildiğinde başarıyı yakalayan ağ üyelerinin blok zincirine eklemek istediği blok bilgi dizini de işlem tarihçesine ve dolayısıyla blok zincirine eklenmiş olur (Morabito, 2017: 25). Bitcoin veya benzeri, herkesin istediği zaman katılabileceği ve üye olabileceği, izin gerektirmeyen ve merkezi otorite tarafindan düzenlenmeyen ağ yapılarında, birbirini tanımayan ve birbirine güven duymayan ağ üyeleri arasında otonom bir şekilde güven sağlamak yukarıdaki şekilde mümkün olmaktadır.

Bitcoin veya diğer kripto para birimlerinin dolaşımını sağlayan blok zincir ağ yapısının en önemli özelliği ise dağıtılmış defter düzeni olarak da adlandırılan, tüm ağ üyelerinin aynı anda, blok zincir ağı oluşturulduğundan bu yana gerçekleşen tüm işlemlerin tarihçesine erişiminin olmasıdır. Bu bilgi erişimi bir bakıma tüm ağ üyelerinin karşıllıklı hesaplarının ve bu hesaplara ilişkin işlemlerin beraber tutulduğu bir muhasebe defteri olarak da düşünülebilir. Bu tür bir yapı ile ağ üyelerinin, SWIFT sistemindeki gibi sıralar halinde değil, aynı anda tüm işlemleri tek bir seferde gerçekleştirmeleri mümkün olabilmektedir, bir bakıma bilgi akışı hızlanmış olmaktadır. Bunun olabilmesi için de, blok zincir ağının Bitcoin örneğindeki gibi belirli bir yöneticisi olmayıp herkesin katılımına açık bir yapısı olabileceği gibi, belirli bir kurum tarafından yönetiliyor ve o kurumun kontrolü ile ağ üyeleri ve yetkilerinin belirleniyor olması da mümkündür. Örneğin Ripple girişimi kendine ait blok zincir ağı ile üyeleri 
Küresel Tedarik Zinciri ve Uluslararası Ticaret Yönetiminde Verimli Ödeme Sistemi Seçimi

arasında gerçekleşen uluslararası ödemeleri yönetmektedir (Wüst ve Gervais, 2018: 4).

Blok zincir ağ yapılarını işlem süresi ve gereken enerji açısından ayrıştıran özelliklerden birisi dağıtılmış deftere eklenecek işlem bloklarının doğruluğunun tüm ağ üyeleri açısından onanmasını sağlayacak oybirliği algoritmasıdır. Bu algoritmanın üç türlü tasarlanması mümkündür: çalışma ispatı (proof-of-work), bahis ispat1 (proof-of-stake) ve Bizans Hata Tolerans1 (practical Byzantine fault tolerance). Çalışma ispatı algoritmasında bazı ağ üyeleri yukarıda da belirtildiği gibi kullanıcıların sanal cüzdanlarından toplanan işlem verilerini blok haline getirerek çözümü zaman ve enerji gerektiren matematiksel bulmacayı ilk çözen ve dağıtılmış deftere işlem bloklarını ekleme yetkisine sahip olarak ödüllendirilecek üye olmayı amaçlarlar. Bitcoin madenciliği bu şekilde bir ödüllendirmeye örnektir. Bu tür oybirliği algoritmaları çok fazla enerji tüketimine yol açmakla eleştirilmektedir. Bahis ispatında ise dağıtılmış deftere blok eklemek isteyen ağ üyeleri, yaptıkları yatırım veya sahip oldukları kripto paranın, ağ içerisinde dolaşan toplam kripto para miktarının kaç yüzdesini oluşturduğuna göre belirlenen bir seçilme şansına sahip olurlar, sanki bu şans ile bahse giriyormuşçasına; ve bu üyeler arasından rasgele bir seçim yapılarak ağa blok ekleyecek olan üye belirlenir. Bu yapının aldığı eleştiri de birbiri ile aynı şansa sahip olan ağ üyeleri arasından seçim yapmanın yavaşlatıcı bir etkisinin olma durumudur. Bizans Hata Toleransı algoritmasında da, her dağıtılmış defter güncellemesi için ağ üyelerinden belirli bir azınlık, tüm ağ üyelerine seçilmek için eşit şans tanınarak rasgele bir şekilde seçilir. Bu üyelerin kimlikleri diğer üyelerden saklanır ve bu seçilmiş üyelerin belirli bir çoğunluğu eklenecek işlemi onaylayacak olursa işlem dağıtılmış deftere eklenir (Swan, 2018: 10-11).

Blok zincir ağ yapısının dağıtılmış defter özelliği sayesinde, finansal işlemler, hesapların bir finansal kurumda gerekli işlemler yapıldıktan sonra diğerinde işlemlerin başlaması şeklinde sıra ile değil, tüm ağ üyesi hesapların aynı anda işlenmesi ile yapılabilir. Bunun için yapılması gereken dağıtılmış defterde tüm hesaplara ilişkin işlem blokunun deftere eklenmesidir. Eş zamanlı işlem yapabilmek de finansal kurumlara işlem maliyetini düşürecek önemli avantajlar sağlamaktadır. Her şeyden önce nakit döngüsünde yaşanan gecikmeler sebebiyle nakit akışının aksamasının, paranın zaman değerinden ötürü ortaya çıkardığı bir maliyet bulunmaktadır. Bunun dışında, uluslararası ödemeler söz konusu olduğunda alıcı ile satıcının para birimleri farklı ise, ödeme talimatı verildikten sonra ödemenin gerçekleşeceği zamana kadar geçen süre ne kadar uzun olursa ödemenin kur dalgalanmalarından etkilenme ihtimali o derece yüksek olacaktır. İşlem süreleri uzadıkça, bu işlemleri gerçekleştirmek için aracı olan muhabir bankalar ve ödemeyi yapan kişinin ve alıcının bankaları gibi finansal kurumlar da birbirleri aralarında tuttukları hesaplarda aktif olarak daha fazla para tutmak zorunda kalmaktadırlar. Daha az likidite ile işlemleri gerçekleştirebilirlerse açığa çıkacak olan parayı daha verimli amaçlar için kullanabilirler. Örneğin Ripple firması sınır-ötesi ödeme hizmeti vermek için 
kurulmuştur, talimat sonrasında ödemeye ilişkin tüm işlemlerin gerçek zamanlı yapılabilmesine olanak sağlayan, dağıtılmış defterin güncellenmesi için işlemleri onama yetkisine sahip üyeleri bulunan hususi bir blok zincir ağ yapısıdır. Ripple firması iki şekilde ödeme işlemlerini gerçekleştirmektedir, birincisi kendi ağında dolaşıma sunulan XRP kripto para birimini farklı para birimleri arasında değişim aracı olarak kullanarak, diğeri ise ödemenin tarafları olan a ğ üyeleri arasında, hesaplarından, gerekirse aracı ağ üyelerinin hesaplarını da aktarma amaçlı kullanarak ödeme miktarının aktarılması şeklindedir. Dolayısıyla Ripple ağ üyeleri arasında sadece SWIFT sistemi ile gerçekleştirilen bilgi aktarımı değil, hesaplarda gerçek zamanlı ödeme aktarımı da yapılabilmektedir (Swan, 2018: 2629). Bu işlemi de, sahip olduğu oybirliği algoritması sayesinde diğer blok zincir ağ yapılarına göre çok daha hızlı gerçekleştirme kapasitesine sahiptir. Örneğin Bitcoin ağında saniyede 3-6 işlem yapılabilirken Ripple ağında saniyede 1500 işlem yapılabilmektedir. Bu sayede sınır-ötesi ödemeler Ripple ile 4 saniye civarı bir zamanda yapılabilmekte iken diğer blok zincir ağlarında 2-60 dakika arası sürmektedir (Ripple, t. y.; Sarwar, 2018).

Dolayısıyla, aracı kurumların komisyonu şeklindeki işlem maliyetleri ve aynı zamanda ödeme işleminin süresinin uzunluğu sebebiyle ortaya çıkan dolaylı maliyetlerde, sınır-ötesi ödemelerde zaman tasarrufu ve diğer verimlilikler sayesinde ciddi düşüşler sağlanabilir. Ripple gibi bir blok zincir ağ yapısı ile gerçekleştirilen sinır-ötesi ödemelerin küresel tedarik zincirlerine sunduğu en önemli avantaj da maliyetlerin düşürülmesi ve işlem hızının arttırılmasıdır (Qiu vd., 2019: 433). Mevcut durumda dünya genelinde ortalama sınır ötesi ödeme işlem maliyeti ödeme miktarının \%7.1'i civarındadır, Dünya Bankası bu miktarı 2030 y1lında \%3'e düşürmeyi planlamaktadır (The World Bank, 2018: 1). Ripple firmasının amacı ise bu ücreti 2030 yılına kadar \%0.3'e düşürmektir. Örneğin bugün 200 US doları civarında bir sınır-ötesi ödeme için yaklaşık 14 dolar ödenirken, Ripple bu ücreti 60 sent gibi bir miktara düşürmeyi hedeflemektedir (Cate, 2018).

Burada da en önemli potansiyel sorunlardan birisi ödeme işleminde yer alan tarafların hak ve sorumluluklarıdır. Ripple ağında üye olan bilgisayar ve terminallerin birbirleri ile iletişimleri Ripple Kurallar Kitabı denilen prosedürler ile düzenlenmektedir. Ripple Kurallar Kitabı'nın güncellenmesi içinse Ripple firmasının danışmanlar kurulu tarafından öneriler geliştirilir ve ağ üzerindeki işlemleri onama yetkisine sahip üyelerin çoğunluğu tarafından onaylanan öneriler kurallar kitabına işlenir (Vanetti, 2018: 16). Ancak bu prosedürler ağ üyelerinin kendileri arasında kabul ettikleri ve benimsedikleri sistem düzenine göre şekillenmektedir, tüm dünyada kabul görmüş blok zincir ağları için düzenlenmiş yasalar bulunmamaktadır, bu sebeple belirli bir kanunlar bütününe dayandırılmaları söz konusu değildir. Eğer blok zincir ağındaki üyelerin dijital cüzdanlarında güvenlik açıklarından kaynaklı para kayıpları olursa blok zincir ağının hukuksal bir sahipliği olmadığı için bu suçu işleyenlerin takibi ve cezalandırılması mümkün olamamaktadır. Blok zincir ağı üzerindeki finansal 
Küresel Tedarik Zinciri ve Uluslararası Ticaret Yönetiminde Verimli Ödeme Sistemi Seçimi

işlemler yasalar 1şığında düzenlenmemiş ve güvenlik açıklarının sorumlulukları için kanunlar da oluşturulmadığ için blok zincir ağlarına dayalı finansal işlemlere finans dünyasının Vahşi Batısı yakıştırması dahi yapılmaktadır (Vennervirta, 2019: 12).

\subsection{SWIFT ve Blok Zincir A $\breve{g}$ ile Ödeme Sistemlerinin Karşılaştırılması}

SWIFT sisteminin en önemli avantajlarından biri uluslararası ticarette sınır-ötesi ödeme talimatlarını standart kodlar haline getirerek işlemlerde geçmişte oluşan kargaşa ve hatalara son vermesi olmuştur. Sunduğu kullanıcı ara yüzü tüm finansal kurumlar tarafından benimsenmiş ve birbirleriyle iletişimleri için gerekli genel usulleri de kolaylaştırmıştır.

Ancak SWIFT sistemi finansal işlemleri yapmadığ 1 ve ana unsur olarak sadece kurumların ödemeler için gerekli iletişimine aracı olduğu için sınır-ötesi ödemelerde işleme dâhil olan tüm kurumlar sıra ile gerekli finansal hesap işlemlerini yapmakta, dolayısıyla her kurumda hesaplarda gerekli ayarlamaların yapılması ayrı ayrı zaman almaktadır. Bu durum herhangi bir ödemenin aldığı toplam zamanın günlerle ölçülecek derecede uzun olmasına sebep olmaktadır. SWIFT ağı GPI atılımı ile işlem süresinde kısalmalar sağlamıştır, ancak her ödeme bu yeniliğin kapsama alanına henüz girememiştir. Bu durumda SWIFT sisteminde hem ödemenin alacağı standart zaman hem de toplam işlem ücreti blok zincir ağına göre daha yüksek olmaktadır (Qiu vd., 2019: 431). Blok zinciri tabanlı ödeme sistemlerinde ise işlemler dağıtılmış deftere sahip tüm ağ üyeleri arasında hem ödeme ile ilgili iletişim hem de finansal işlemlerin eş zamanlı gerçekleştirilmesiyle yürüdüğünden SWIFT sistemindeki bekleme süreleri ve buna dayanan yüksek komisyonlar söz konusu değildir. Ayrıca finansal kurumların tabi olduğu ofis çalışma saatleri kısıtı da çevrimiçi bir sistem olduğu için blok zinciri için söz konusu olmayabilir, bu da sınır-ötesi ödeme işlemlerinin blok zincir ağlarında hem daha kısa sürede hem de göreceli olarak SWIFT sistemine göre daha düşük bir maliyetle gerçekleştirilmesini sağlamaktadır (Qiu vd., 2019: 433). Örneğin yukarıda da bahsedildiği gibi Ripple firması sınır-ötesi ödemelerin ücretini 2030 yılında ödeme miktarının \%0.3'üne düşürmeyi hedeflemekte ve hali hazırda işlem süresini de 4 saniyeye düşürmüş bulunmaktadir.

Blok zincir ağı sayesinde gerçekleştirilen sınır-ötesi ödemelerde zaman ve maliyetler açısından tasarruf söz konusu olmakla beraber, bir dezavantaj olarak çok yeni bir bilgi işlem sistemi olduğu için SWIFT sistemi gibi tüm dünyada yaygınlaşmış değildir. SWIFT sistemi dünya çapında binlerce finansal kurum tarafindan kullanılmaktadır ve SWIFT sistemine ait ödeme talimat kodları ve kullanıcı ara yüzü tüm bu kurumlar tarafından benimsenmiş bulunmaktadır. Ancak dünya çapında bu sayıda finansal kurumu bünyesinde toplayan bir blok zincir ağı henüz oluşturulamamıştır. Bunun sebebi kullanılan şifreleme bilimi yöntemlerinin henüz tam olgunluğa erişmemiş olmasıdır (Deshpande vd., 2017: 6). Dünya genelinde farklı farklı finansal kurumlar arasında blok zincir oluşturma 
girişimleri eş zamanlı olarak bu teknolojiyi olgunluğa ulaştırmaya çalışmakta, hepsinin de farklı farklı üye finansal kurum portföyleri bulunmaktadır.

Blok zincir ağının ortaya çıkardığı diğer bir olası sıkıntı da bilginin ve verilerin korunması ile ilgilidir. İki açıdan bu konuda sorunlar olabilir. Kullanılan teknoloji henüz tam olgunlaşmadığı için kodlar ve sistem hataya ve veri koruma boşluklarına daha açıktır. Blok zincir ağına gerçekleştirilebilecek saldırılar üç başlık altında toplanabilir: kripto paralara ait bilgilerin saklandığı sanal cüzdan uygulamalarına yapılan saldırılar ile paraların çalınması, blok zincir ağına birden fazla IP adresi ile üye olunarak ağdaki hizmetlerin kasitlı olarak aksamasına sebep olunması (denial of service attack) ve ağdaki hesaplama kapasitesinin \%50'sinden fazlasının ele geçirilerek a ğ üzerindeki kripto paralara el konulması (51\% hash rate attack). Teknik olarak bu saldırılara cevap vermek için ağ tamamen veya belirli bir süreliğine kapatmak ve bu arada algoritmayı güncellemek gerekmektedir. Ancak herhangi bir hukuksal koruma olmadığ i için, böyle durumlarda özellikle, kripto paraların itibari parayla (fiat currency) alış verişini yapan kurumlar ve ayrıca kripto para yatırımcıları büyük zararlara uğramaktadır. Örneğin Mt. Gox adlı kurum bitcoin alış verişinin \%70'inden sorumluydu ve saldırı sonucunda 350 milyon US doları kaybedildi, müşterilerine ise sadece sistemlerini kapattıklarını belirten kısa bir yazı ile bilgi verdiler. Zararların karşılanması için hukuksal bir dayanak olmadığı için bu gibi kurumlar hiçbir sorumluluk almamakla beraber müşterilerine detaylı bir bilgi vermeye bile tenezzül etmemektedirler (Beck vd., 2017: 130-131).

Blok zincir ağlarında verilerin korunması ile ilgili yapılan hatalara bir başka örnek olarak, 150 milyon dolarlık kitlesel fonlama ile oluşturulan bir blok zincir ağı olan Decentralized Autonomous Organization (DAO) ağının korsan saldırılar sonucu ortadan kaldırılması verilebilir (Ishmaev, 2017: 668). Blok zincir ağının genel altyapısına ve kullanıcıların kişisel verilerine yapılabilecek korsan saldırılar dışında blok zincir ağı ile otomatik olarak gerçekleştirilen işlemlerde de veri açılları verilmesi mümkün olabilir (Mosakheil, 2018: 53). Blok zincirlerinde veri güvenliğinin sağlanması, para ve gizlilik mağduriyetleri yaşanmaması adına giderilmesi gereken önemli ihtiyaçlardan biridir (Achanta, 2018: 4).

Bundan dolayı blok zincir ağları ile yapılan finansal işlemlerde bir para kaybı olursa bu kayba uğrayan tarafların, örneğin bir sınır-ötesi ödemenin taraflarının, herhangi bir muhatap bulamamaları riski bulunmaktadır (Rosner ve Kang, 2015: 651). Hem ödeme miktarını tamamen kaybetmeleri hem de tekrar ödeme yapmak durumunda kalınacağı için gecikmeden doğan pek çok maliyeti üstlenmek durumunda kalmaları mümkündür (Deshpande vd., 2017: 6; Oh ve Shong, 2017: 337). Blok zincir ağı ile yapılan sınır-ötesi ödemelerin oluşturduğu bu risk, hukuksal dayanakların ve emsal sayılabilecek pek çok yasal kararın yıllar boyunca geliştirilmiş olduğu SWIFT sistemi için söz konusu değildir (Demeyer, 2018: 47). 
Küresel Tedarik Zinciri ve Uluslararası Ticaret Yönetiminde Verimli Ödeme Sistemi Seçimi

Yukarıdaki açıklamalar doğrultusunda bir sınır-ötesi ödemenin SWIFT ve blok zincir ağları ile yapılması durumunda ortaya çıkaracağı maliyet ve riskleri şu açılardan karşılaştırmak mümkündür:

1) Finansal kurumlara ödenecek maliyetler: mevcut durumda SWIFT sistemi gibi standart metotlar için komisyon maliyeti ödemenin yaklaşı \%7.1'idir (The World Bank, 2018: 1). Blok zincir ağları için 0-1 dolar arası veya Bitcoin için 30 dolara yakın seyretmekte ve 2030 yılı için Ripple gibi firmalar tarafindan \%0.3'e düşmesi hedeflenmektedir (Sarwar, 2018). Ödeme miktarına göre ödemenin \%3'ü ile \%1'den düşük miktarlar arasında yer alır.

2) Ödemenin alacağı zamanda faiz getirisi ve döviz kuru dalgalanmaları açısından yaşanabilecek kayıplar: SWIFT sisteminde ödemelerin, sistemin kullanılan sürümüne göre 30 dakika, 24 saatten az veya 3-5 gün arası bir süre aldığ zincir ağında ise ödemelerin gerçekleştirilme süreleri 3-4 saniye ile 1 saat arasında değişmektedir (Sarwar, 2018). SWIFT ağı ve/veya üyeleri faiz kaybı ile ilgili bir sorumluluk alabilse de döviz kuru dalgalanmaları açısından ödemenin taraflarını hukuksal olarak koruyacak bir yapı bulunmamaktadır. Ancak blok zincir ağında bu iki tür kayıp da, eğer gerçekleşirse mağduriyet yaratacaktır.

3) Ödemenin yerine ulaşamaması ve ödeme miktarının tamamen kaybolmasından dolayı yaşanacak kayıplar: SWIFT sisteminde ödemenin ulaştırılmasında hata yapılsa bile ödemenin taraflarını koruyacak gerekli teknolojik ve hukuksal düzenlemeler bulunmaktadır. Ancak blok zincir ağları teknolojisi henüz tam olgunlaşmamış ve yaygınlaşmamıştır. Veri açıkları ortaya çıkabilir ve daha da önemlisi henüz hukuksal olarak yönetimi ve standartları da ortaya konmamıştır. $\mathrm{Bu}$ sebeplerden dolayı veri açıkları olduğunda tamamlanamayan ve kaybedilen ödeme miktarının kim tarafindan tazmin edileceği belirsizliğini korumaktadır ve blok zincir ağlarında sınır-ötesi ödemelerde ödeme miktarının kaybedilmesi riski söz konusudur (Beck vd., 2017: 130-131). Bu durumda ayrıca yeni bir ödeme yapılana kadar faiz ve döviz kuru dalgalanmalarından kaynaklanan kayıplar da mağduriyet yaratacaktır.

\section{Yöntem}

Bu çalışmada, sınır-ötesi ödemeler için tercih edilebilecek iki ayrı ödeme sistemi olan SWIFT ve blok zincir ağ tabanlı ödeme sistemleri için, gönderici tarafindan hangi sistemin seçilmesinin hangi ölçütlere göre daha uygun olacağ ile ilgili bir karar mekanizması önerilmesi hedeflenmiştir. Küresel tedarik zincirlerinde en büyüklenmesi gereken miktar tedarik zincirinin yarattığı toplam değerdir. $\mathrm{Bu}$ değer de son kullanıcının ürüne ödediği miktardan tedarik zinciri boyunca oluşan tüm maliyetlerin çıkarılması ile elde edilmektedir. Sınır-ötesi ödemelerin ortaya koyacağ ortaya çıkan maliyetler arasında yer aldığından çalışmada kullanılan model küresel bir tedarik zincirinde tedarik zinciri değerini arttıracak bir karar politikası ortaya koymayı amaçlamaktadır (Chopra ve Meindl, 2013: 15). 
$\mathrm{Bu}$ hedefe ulaşmak için öncelikle iki ayrı ödeme sisteminin seçilmesi durumunda ortaya koyacağı maliyet ve risklerin nasıl sayısallaştırılabileceği belirtilecek, sonrasında ise bu sayısal değerlerin nasıl kıyaslanabileceği ile ilgili, olasılık literatüründen faydalanılarak öneriler ortaya konacaktır.

Sınır-ötesi ödeme için SWIFT sistemi seçimi ödemeyi gönderici tarafından göz önüne alınıyorsa banka veya ödeme hizmetini üstlenecek finansal kurum tarafindan alınacak tüm komisyon ücretleri (SWIFT ağı, muhabir bankalar ve alıcının bankası dâhil olmak üzere) göndericiye net bir şekilde belirtilir. Yukarıda da belirtildiği üzere bu komisyon ücretleri ödeme miktarının belirli bir yüzdesi olarak finans piyasalarında ele alınmaktadır. Dolayısıyla komisyon ücretleri ile ilgili ödeme sistemini yapacak olan gönderici açısından bir belirsizlik tecrübe edilmez. Ancak süre konusunda bir taahhüt verilememektedir ve yine yukarıda belirtildiği üzere SWIFT sisteminde ödeme süreleri günler alabilir. Bu durumda eğer faiz getirisi kaynaklı kayıplar olursa SWIFT ya da bankanın bu kayıpları karşılaması için gerekli düzenlemeler bulunmaktadır, ancak döviz kuru dalgalanmasından kaynaklı, alıcının bir kaybı olursa bu tür bir kaybın karşılanması için hazırda bir hukuksal düzenleme bulunmamaktadır. Gönderici ile alıcı arasındaki anlaşmaya göre, bu kayıp gönderici tarafından karşılanmak durumunda ise gönderici açısından bir risk oluşturmaktadır.

Dolayısıyla SWIFT sistemi ile sınır-ötesi ödeme gerçekleştirilecek olursa iki tür finansal maliyet/kayıp olabilir: 1) ödeme için göndericiden alınacak komisyon ve işlem ücreti, 2) ödeme esnasında döviz kurunda dalgalanma olursa göndericinin alıcıya ödemek zorunda kalabileceği fark. Bu iki miktarın toplamı ödemenin göndericiye toplam bedelini oluşturacaktır ve ödeme sistemi seçimi kararı esnasında bir rassal değişken şeklinde matematiksel olarak ifade edilebilir. İlgili notasyon aşağıda belirtilmiştir:

Tablo 1. SWIFT Sistemine Ait Maliyet/Kayıplar için Değişken ve Parametreler

\begin{tabular}{|r|l|}
\hline$M$ & $\begin{array}{l}\text { : Gönderilecek olan ödeme miktarı (USD veya EURO gibi ticari bir para birimi } \\
\text { cinsinden ele alınacaktır.) }\end{array}$ \\
\hline$k_{S}$ & $\begin{array}{l}\text { : SWIFT sistemi için işlem ve komisyon ücreti (Ödeme miktarının belirli bir } \\
\text { yüzdesi şeklinde ele alınacaktır.) }\end{array}$ \\
\hline$t^{S}$ & $\begin{array}{l}\text { : SWIFT ile yapılacak ödemenin süresi (Gün cinsinden ele alınmıştır, } t^{S} \in\{0,1, \\
\text {.., N\} şeklinde kesikli rassal dağılıma sahiptir, } t^{S}=0 \text { değeri ödemenin aynı gün } \\
\text { içinde alıcının hesabına geçtiği durumu ifade etmektedir, N ise SWIFT sisteminin } \\
\text { teknik olanaklarına ve yukarıda belirtilen literatüre dayanarak 1 ile } 5 \text { gün arası bir } \\
\text { süre olarak alınabilir.) }\end{array}$ \\
\hline$r(0) v e$ & $\begin{array}{l}\text { : Ödemenin talimatının verildiği gün (0 ile gösterilmektedir.) ve alıcının hesabına } \\
\left.\text { geçtiği gündeki ( } t^{S}\right), \text { alıcı açısından döviz kuru oranları (Ödemenin para } \\
\text { birimi/Alıcının para birimi şeklinde ele alınacaktır.) }\end{array}$ \\
\hline$r\left(t^{S}\right)$ & $\begin{array}{l}\text { Gönderici açısından ödeme yapıldıktan ( } t^{S} \text { adet gün geçtikten) sonra oluşacak } \\
\text { kayıpların gönderim esnasındaki zaman değerini belirten iskonto oranı }\end{array}$ \\
\hline[]$^{+}$ & $\begin{array}{l}\text { : Bir ifadenin negatif olması durumunda 0 değerini, diğer durumlarda ise kendi } \\
\text { değerini veren fonksiyonu temsil eder. }\end{array}$ \\
\hline
\end{tabular}


Küresel Tedarik Zinciri ve Uluslararası Ticaret Yönetiminde Verimli Ödeme Sistemi Seçimi

SWIFT sistemine ait toplam maliyet ve kayıpların, ödeme sistemi seçim kararı esnasındaki değeri, bir rassal değişken olarak şu şekilde belirtilebilir:

$$
\mathrm{C}_{\text {SwIFT }} \sim M * k_{S}+M *\left[\frac{r(0)}{r\left(t^{S}\right)}-1\right]^{+} * d\left(t^{S}\right)
$$

İfadenin ilk terimi göndericiye kesin olarak belirtilen işlem ve komisyon ücretlerini, ikinci terimi ise rassal olan ödeme süresi esnasında ortaya çıkabilecek ve yine rassal değişken olan (ödemenin para birimi/alıcının para birimi) kur farkından kaynaklı, göndericinin katlanmak durumunda kalabileceği kaybın ödeme sistemi seçimi esnasındaki değerini ifade etmektedir.

Sınır-ötesi ödeme için blok zincir ağı ile ödeme sistemi gönderici tarafından göz önüne alınıyorsa banka veya ödeme hizmetini üstlenecek finansal kurum tarafindan alınacak tüm komisyon ücretleri, yine SWIFT sistemindeki gibi göndericiye net bir şekilde belirtilir. Yukarıda da belirtildiği üzere bu komisyon ücretleri ödeme miktarının belirli bir yüzdesi olarak finans piyasalarında ele alınmaktadır. Dolayısıyla komisyon ücretleri ile ilgili ödeme sistemini yapacak olan gönderici açısından bir belirsizlik tecrübe edilmez. Blok zincir ağı ile ödeme sistemi seçiminde göndericinin karşılaşabileceği en önemli belirsizlik ödeme ile ilgili, ağ üzerinde veya dijital cüzdan ve benzeri uygulamalarda bir sorun yaşanması ve ödemenin kaybedilmesi durumudur. Böyle durumlarda blok zincir ağları ile ilgili hiçbir hukuksal düzenleme bulunmadığı için göndericinin hakkını arayabileceği bir mekanizma da söz konusu değildir. Ödemenin kaybedilmesi durumunda ödeme miktarının yanında, alıcıya yeni bir ödeme yapana kadar oluşacak faiz getirisi ve döviz kuru dalgalanmalarından kaynaklı kayıplar da yine göndericiye yük olacaktır. Ancak bir sorun yaşanmaz ve ödeme gerçekleştirilirse en çok kullanılan blok zincir sınır-ötesi ödeme ağlarının tümünde aynı gün içerisinde ödeme alıcının hesabına geçebilecek ve faiz kayıpları veya döviz kuru dalgalanma kayıpları göz ardı edilebilecek düzeyde az olacaktır.

Dolayısıyla blok zincir ağı ödeme sistemi ile sınır-ötesi ödeme tercih edilecek olursa iki tür finansal maliyet/kayıp olabilir: ödeme için göndericiden alınacak komisyon ve işlem ücreti ile ödeme başarısız olursa ödeme miktarı ile beraber yeni bir ödeme yapılana kadar oluşacak faiz getirisi ve döviz kuru odaklı kayıplar. Yeni bir ödeme talimatı verildiği andan itibaren olan maliyet/kayıplar, ikinci ödeme için farklı bir sistem seçilebileceğinden, ilk ödeme sistemi için seçim kararının etkilerine dâhil edilmemiştir. Bu iki miktarın toplamı ödemenin göndericiye toplam bedelini oluşturacaktır ve ödeme sistemi seçimi kararı esnasında bir rassal değişken şeklinde matematiksel olarak ifade edilebilir. İlgili notasyon aşağıda belirtilmiştir: 
Tablo 2. Blok Zincir Ăğ Sinır-ötesi Ödeme Sistemine Ait Maliyet/Kayıplar için Değişken ve Parametreler

\begin{tabular}{|c|c|}
\hline$M$ & $\begin{array}{l}\text { : Gönderilecek olan ödeme miktarı (USD veya EURO gibi ticari bir para } \\
\text { birimi cinsinden ele alınacaktır.) }\end{array}$ \\
\hline$k_{B}$ & $\begin{array}{l}\text { : Blok zincir tabanlı sınır-ötesi ödeme sistemi için işlem ve komisyon } \\
\text { ücreti (Ödeme miktarının belirli bir yüzdesi şeklinde ele alınacaktır.) }\end{array}$ \\
\hline 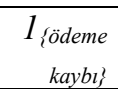 & 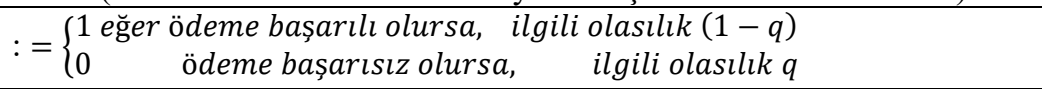 \\
\hline$t^{B}$ & $\begin{array}{l}\text { : ödemenin kaybedilmesi durumunda, ödeme talimatı verildiği günden, } \\
\text { alıcının ikinci ödemeyi gerçekleştireceği duruma kadar geçecek olan gün } \\
\text { sayısı }\left(t^{B} \in\{0,1, \ldots, Z\} \text { şeklinde kesikli rassal dağllıma sahip veya alıcının }\right. \\
\text { ekonomik gücüne göre kesin bir zaman dilimi olarak da ele alınabilir. }\end{array}$ \\
\hline $\begin{array}{r}r(0) v e \\
r\left(t^{B}\right)\end{array}$ & $\begin{array}{l}\text { : Ödemenin başarısız olması ve kaybedilmesi durumunda ilk ve ikinci } \\
\text { ödeme talimatlarının verildiği günlerde alıcı açısından döviz kuru oranı } \\
\text { (Ödemenin para birimi/Alıcının para birimi şeklinde ele alınacaktır.) }\end{array}$ \\
\hline$d\left(t^{B}\right)$ & $\begin{array}{l}\text { : Ödemenin başarısız olması ve kaybedilmesi durumunda ikici ödeme } \\
\text { yapılana kadar gönderici açısından oluşacak kayıpların gönderim } \\
\text { esnasındaki zaman değerini belirten iskonto oranı }\end{array}$ \\
\hline
\end{tabular}

Blok zincir ağı ile sınır-ötesi ödeme sistemine ait toplam maliyet ve kayıpların, ödeme sistemi seçim kararı esnasındaki değeri, bir rassal değişken olarak şu şekilde belirtilebilir:

$\mathrm{C}_{\text {BLOCK ChAIN }} \sim M * k_{B}+1_{\{\text {ödeme kaybl }\}} *\left[M+M *\left[\frac{r(0)}{r\left(t^{B}\right)}-1\right]^{+} * d\left(t^{B}\right)\right]$

İfadenin ilk terimi göndericiye kesin olarak iletilen işlem ve komisyon ücretlerini, ikinci terimi ise ödemenin kaybedilmesi durumunda ödeme miktarının değerine ek olarak rassal bir değişken olan (ödemenin para birimi/alıcının para birimi) kur farkından kaynaklı, göndericinin katlanmak durumunda kalabileceği kaybın ödeme sistemi seçimi esnasındaki değerini ifade etmektedir.

$\mathrm{Bu}$ modelleme ışığında bir sınır-ötesi ödeme için ödemenin göndericisinin karşılaştı̆̆ karar problemi ödeme sistemlerinin getireceği toplam maliyet/kayıpları temsil eden iki rassal değişkenin olasılıksal/stokastik karşılaştırması şeklindedir. Bu tür bir karşılaştırma için literatürde geliştirilen ve bu araştırmada kullanılacak olan tanımlar ve teoremler aşağıda belirtilmiştir.

Tanım 1: $\mathrm{X}$ ve $\mathrm{Y}$ rassal değişkenleri için stokastik baskınlık iki şekilde tanımlanabilir ( $E$ ifadesi beklenen değer fonksiyonunu, $f$ ise bir matematiksel fonksiyonu ifade etmektedir):

1) Birinci dereceden stokastik baskınlık: Eğer tüm artan (increasing) $f$ fonksiyonları için $E f(X) \leq E f(Y)$ sağlanıyorsa, $X \leq_{s t} Y$,

2) İkinci dereceden stokastik baskınlık: Ĕger tüm artan dışbükey (increasing convex) $f$ fonksiyonları için $E f(X) \leq E f(Y)$ sağlanıyorsa, $X \leq_{i c x} Y$, 
Küresel Tedarik Zinciri ve Uluslararası Ticaret Yönetiminde Verimli Ödeme Sistemi Seçimi

3) Eğer tüm dışbükey (convex) $f$ fonksiyonları için $E f(X) \leq E f(Y)$ sağlanıyorsa, $X \leq_{c x} Y$.

Riske duyarsız (risk-neutral) rasyonel bir karar verici için iki rassal maliyetten birinci dereceden stokastik baskınlık açısından küçük olan rassal maliyeti temsil eden sistem tercih edilmelidir. Riskten sakınan (risk-averse) bir karar verici içinse ikinci dereceden stokastik baskınlık açısından küçük olan rassal maliyeti temsil eden sistem tercih edilmelidir (Müller ve Stoyan, 2002: 215; Stiglitz ve Rothschild, 1970: 226). Bu değerlendirmeleri yapabilmek için karşılaştırılacak rassal maliyetlerin olasılık dağılımları kullanılarak belli ölçütler geliştirilmiştir ve bu ölçütlerden araştırmada kullanılacak olanlar aşağıdaki teoremde özetlenmiştir.

Teorem 1: $\mathrm{X}$ ve $\mathrm{Y}$ rassal değişkenlerinin olasılık dağılım fonksiyonları $F_{X}$ ve $F_{Y}$ şeklinde belirtilerek $\left(F_{X}(t):=P(X \leq t), \quad t \in \mathbb{R}\right)$, aşağıdaki ifade denklikleri ve ilişkileri söz konusudur:

1) $X \leq_{s t} Y \Leftrightarrow F_{X}(t) \geq F_{Y}(t) \forall t \in \mathbb{R}$,

2) $X \leq_{c x} Y \Rightarrow X \leq_{i c x} Y$,

$X \leq_{c x} Y \Leftrightarrow E[X]=E[Y] \wedge \int_{t}^{\infty}\left[1-F_{X}(s)\right] d s \leq \int_{t}^{\infty}\left[1-F_{Y}(s)\right] d s \quad \forall t \in \mathbb{R}$ (İspatı için Bäuerle ve Müller, 2006: 3-5).

Karar verici riske duyarsız ise $X \leq_{s t} Y$ kıyaslamasına göre küçük olan ödeme şeklini, riskten sakınıyorsa $X \leq_{i c x} Y$ kıyaslamasına göre kü̧̈ük olan ödeme şeklini benimsemelidir. Bu karar ve dolayısıyla bu bağlantıların hangi koşullarda söz konusu olabileceği ise $\mathrm{C}_{\text {SWIFT }}$ ve $\mathrm{C}_{\text {BLOCK CHAIN }}$ rassal değişkenlerini oluşturan, Tablo 1 ve Tablo 2'de belirtilen parametre ve rassal değişkenlere bağlıdır. Bir sonraki bölümde karar vericinin içinde bulunduğu koşullara dayalı olarak bu bağlantıların nasıl incelenebileceği tartışılacak ve örnekler verilecektir.

\section{Bulgular ve Yorumlar}

Riske duyarsız bir gönderici için, $\mathrm{C}_{\text {SWIFT }} \leq_{s t} \mathrm{C}_{\text {BLOCK CHAIN }}$ ise SWIFT sistemi, tam tersi olması durumunda da blok zincir ağı ile gönderim yapılmalıdır. Teorem 1'den yola çıkılarak $F_{C_{S W I F T}}(t) \geq F_{C_{B L O C K ~ C H A I N}}(t) \forall t \in \mathbb{R}$ ise SWIFT sistemi ile ödeme gerçekleştirilmelidir. Bu bağlantıyı teyit edebilmek için iki rassal değişkenin de olasılık dağılımlarının tanımlanmasına ihtiyaç duyulur. Aşağıdaki denklemlerde, (1) ve (2) no'lu denklemlerden yararlanarak bu olasılık dağglımları analiz edilmektedir. $f_{X}, X$ rassal değişkeninin olasılık yoğunluk fonksiyonunu temsil etmekte ve döviz kuru ile faiz oranına ait olasilık dağılımlarının birbirinden bağımsız olduğu varsayılmaktadır. Türkiye için bu varsayımın kabul edilmesi söz konusu olabilir (Karaca, 2005: 1). Farklı ülkeler için bu varsayım geçerli olmayabilir, bu durumda matematiksel notasyonu döviz kuru ve faiz oranı için birleşik olasılık dağılımı kullanarak düzenlemek mümkündür.

$P\left(C_{\text {SWIFT }} \leq t\right)=P\left(M * k_{S}+M *\left[\frac{r(0)}{r\left(t^{S}\right)}-1\right]^{+} * d\left(t^{S}\right) \leq t\right)$ 


$$
\begin{aligned}
& P\left(M * k_{S}+M *\left[\frac{r(0)}{r\left(t^{S}\right)}-1\right]^{+} * d\left(t^{S}\right) \leq t\right)=P\left(\left[\frac{r(0)}{r\left(t^{S}\right)}-1\right]^{+} * d\left(t^{S}\right) \leq \frac{t}{M}-k_{S}\right) \\
& P\left(\left[\frac{r(0)}{r\left(t^{S}\right)}-1\right]^{+} * d\left(t^{S}\right) \leq \frac{t}{M}-k_{S}\right) \\
& =\int_{\left\{x, y, z: 0 \leq x * y \leq \frac{t}{M}-k_{S}\right\}} f_{\left[\frac{r(0)}{r\left(t^{S}\right)}-1\right]^{+}(x \mid z) * f_{d\left(t^{S}\right)}(y \mid z) * f_{t^{S}}(z) d x d y d z} \\
& P\left(C_{B L O C K C H A I N} \leq t\right) \\
& =P\left(M * k_{B}+1_{\{\ddot{x d e m e ~ k a y b l\}}\}} *\left[M+M *\left[\frac{r(0)}{r\left(t^{B}\right)}-1\right]^{+} * d\left(t^{B}\right)\right] \leq t\right) \\
& =(1-q) * P\left(k_{B} \leq \frac{t}{M}\right)+q * P\left(\left[\frac{r(0)}{r\left(t^{B}\right)}-1\right]^{+} * d\left(t^{B}\right) \leq \frac{t}{M}-1-k_{B}\right) \\
& =\left\{\begin{array}{c}
0, \quad \text { if } \frac{t}{M}-k_{B}<0 \\
(1-q), \quad \text { if } 0 \leq \frac{t}{M}-k_{B}<1 \\
(1-q)+q * \int_{\left\{x, y, z: 0 \leq x * y \leq \frac{t}{M}-1-k_{B}\right\}} f_{\left[\frac{r(0)}{r\left(t^{B}\right)}-1\right]^{+}}(x \mid z) * f_{d\left(t^{B}\right)}(y \mid z) * f_{t^{B}}(z) d x d y d z
\end{array}\right.
\end{aligned}
$$

Yukarıdaki denklemlerden de anlaşılacağ

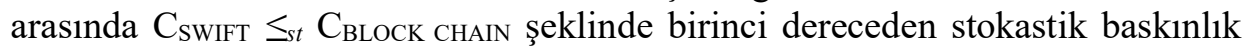
açısından bir kanıya varabilmek için, SWIFT ağında ödemenin gerçekleştirilme süresi, döviz kuru, iskonto oranı, blok zincir ağında ödeme kaybı ihtimali, blok zincir ağında ödeme kaybı olursa yeniden ödeme yapana kadar geçecek olan süre rassal olgularının davranışları hakkında bilgi sahibi olmak gerekmektedir. Uygulamada bu derece geniş kapsamlı verilere sahip olmak mümkün olmayabilir, ancak çeşitli yakınsamalar kullanarak karar mekanizmasını kullanabilmek söz konusu olabilir. Buna dair bir örnek aşağıdaki şekilde verilebilir.

Örnek 1: SWIFT GPI ile blok zincir ağının karşılaştırılması için, literatür bölümünde yer verilen bilgilere de dayanarak, $k_{S}=0,071, k_{B}=0,03$ ve $t^{S} \in\{0,1\}$, $\mathrm{P}\left(t^{S}=0\right)=\mathrm{P}\left(t^{S}=1\right)=0,5$ alınabilir. Döviz kuru değişimi için olasılık dağ 1 lımı elde etmek mümkün değilse finans kurumları tarafından yayınlanan tahminler yakınsama değerleri olarak kullanılabilir. Ödeme miktarının USD cinsinden olduğu ve alıcının da Türkiye'de olduğunu varsayarsak, ödeme talimatının verildiği gündeki USD/TRY döviz kuru $\mathrm{r}(0)=6,816$, ödemenin sonuçlanabileceği sonraki gün için de döviz kuru tahmini $\mathrm{r}(1)=6,780$ şeklinde tahmin ediliyorsa bu değerler yakınsama için kullanılabilir. Böyle bir durumda $\left[\frac{r(0)}{r\left(t^{s}\right)}-1\right]^{+}=$ $\left[\frac{6,816}{6,780}-1\right]^{+}=0,00531$ alınacaktır. İskonto oranı ise y1llı \%10 faiz üzerinden $\mathrm{d}(0)=1, \mathrm{~d}(1)=10 / 36500=0,000273973 \cong 0.0003$ alınabilir. Dolayısıyla alıcının 
Küresel Tedarik Zinciri ve Uluslararası Ticaret Yönetiminde Verimli Ödeme Sistemi Seçimi

Türkiye gibi bir ülkede olduğu düşünülürse $0 \leq\left[\frac{r(0)}{r\left(t^{S}\right)}-1\right]^{+} * d\left(t^{S}\right) \ll 1$ olduğu söylenebilir. Bu durumda blok zincir ağı için de $0 \leq\left[\frac{r(0)}{r\left(t^{B}\right)}-1\right]^{+}$* $d\left(t^{B}\right) \ll 1$ ilişkisi geçerli alınabilir. Bu şartlarda $\mathrm{C}_{\text {SwIFT }}$ ve $\mathrm{C}_{\text {BLOCK CHAIN }}$ rassal değişkenlerinin davranışları aşağıdaki şekilde özetlenebilir.

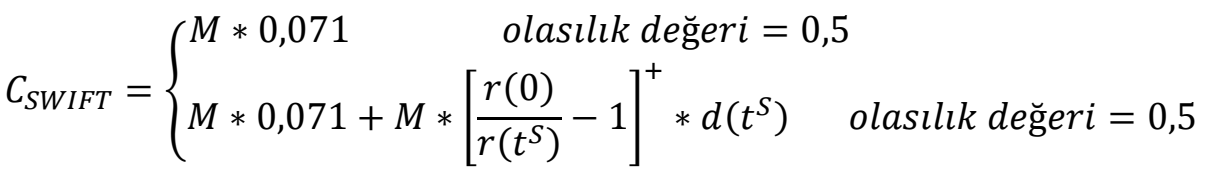

$C_{\text {BLOCK CHAIN }} \quad$ olasılı de ğeri $=1-q$
$=\left\{\begin{array}{l}M * 0,03 \quad \text { olasılık değeri }=q \\ M * 0,03+M+M *\left[\frac{r(0)}{r\left(t^{B}\right)}-1\right]^{+} * d\left(t^{B}\right)\end{array}\right.$

$\mathrm{Bu}$ durumda $F_{C_{S W I F T}}(t)$ ve $F_{C_{B L O C K ~ C H A I N}}(t) \forall t \in \mathbb{R}$ için aşağıdaki tablodaki durum söz konusudur. Tabloda notasyonu kolaylaştırmak açısından $r_{S}=\left[\frac{r(0)}{r\left(t^{S}\right)}-1\right]^{+} * d\left(t^{S}\right)$ ile $r_{B}=\left[\frac{r(0)}{r\left(t^{B}\right)}-1\right]^{+} * d\left(t^{B}\right)$ ile gösterilmiştir.

Tablo 3. Örnek 1 için SWIFT ve Blok Zincir Ă̆g Sinır-ötesi Ödeme Sistemleri Toplam Maliyet Olasılık Dă̆glımı Karşılaşstırması

\begin{tabular}{|l|l|l|}
\hline \multicolumn{1}{|c|}{ Değer Aralığı } & $F_{C_{S W I F T}}(t)$ & \multicolumn{1}{|c|}{$F_{C_{\text {BLOCKCHAIN }}(t)}$} \\
\hline$t \leq M * 0,03$ & 0 & 0 \\
\hline$M * 0,03 \leq t \leq M * 0,071$ & 0 & $1-\mathrm{q}$ \\
\hline$M * 0,071 \leq t \leq M * 0,071+M * r_{S}$ & 0,5 & $1-\mathrm{q}$ \\
\hline$M * 0,071+M * r_{S} \leq t \leq M * 0,03+M+M * r_{B}$ & 1 & $1-\mathrm{q}$ \\
\hline$M * 0,03+M+M * r_{B} \leq t$ & 1 & 1 \\
\hline
\end{tabular}

Tablo 3'ten de anlaşılacağı üzere blok zincir ağında ödeme kaybı ihtimali q $>0$ olursa iki sistem arasında, mevcut koşullarda, Tanım 1 ve Teorem 1'e göre birinci dereceden stokastik baskınlık açısından net bir tercih edilebilirlik görülememektedir. Ancak blok zincir ağının güvenilirliği \%100 olursa, dolayısı ile $\mathrm{q}=0$ olursa riske duyarsız bir gönderici tarafından blok zincir ağ 1 ile gönderim tercih edilecektir. Bunun en önemli sebebi ise blok zincir ağında ödeme kaybı olduğunda ödeme miktarının SWIFT ağındaki gibi karşılanmamasıdır. Eğer bu ödemeyi blok zincir ağı yöneticileri tazmin edecek olurlarsa ve bu sayede işlem ücretinin daha az olması bir avantaj haline gelirse $\left(M * 0,03+M * r_{B} \leq M *\right.$ $\left.0,071+M * r_{S}\right)$ iki ödeme sisteminin toplam maliyetlerinin stokastik kıyaslaması aşağıdaki gibi değiş̧ebilir. 
Tablo 4. Örnek 1 için SWIFT ve Blok Zincir Ă̆g Sinır-ötesi Ödeme Sistemleri Toplam Maliyet Olasılık Dağılımı Karşılaştırması (blok zincir ă̆ında ödeme kaybı durumunda ağın kendisi tarafindan karşılanması senaryosu)

\begin{tabular}{|c|l|l|}
\hline $\begin{array}{c}\text { Değer Aralığ }\left(M * 0,071 \leq M * 0,03+M * r_{B} \leq M *\right. \\
\left.0,071+M * r_{S}\right)\end{array}$ & $F_{C_{\text {SWIFT }}(t)}$ & $F_{C_{\text {BLOCK CHAIN }}}(t)$ \\
\hline$t \leq M * 0,03$ & 0 & 0 \\
\hline$M * 0,03 \leq t \leq M * 0,071$ & 0 & $1-\mathrm{q}$ \\
\hline$M * 0,071 \leq t \leq M * 0,03+M * r_{B}$ & 0,5 & $1-\mathrm{q}$ \\
\hline$M * 0,03+M * r_{B} \leq t \leq M * 0,071+M * r_{S}$ & 0,5 & 1 \\
\hline$M * 0,071+M * r_{S} \leq t$ & 1 & 1 \\
\hline Değer Aralığ $\left(M * 0,03+M * r_{B} \leq M * 0,071\right)$ & $F_{C_{S W I F T}}(t)$ & \multicolumn{1}{|c|}{$F_{C_{B L O C K C H A I N}}(t)$} \\
\hline$t \leq M * 0,03$ & 0 & 0 \\
\hline$M * 0,03 \leq t \leq M * 0,03+M * r_{B}$ & 0 & $1-\mathrm{q}$ \\
\hline$M * 0,03+M * r_{B} \leq t \leq M * 0,071$ & 0 & 1 \\
\hline$M * 0,071 \leq t \leq M * 0,071+M * r_{S}$ & 0,5 & 1 \\
\hline$M * 0,071+M * r_{S} \leq t$ & 1 & 1 \\
\hline
\end{tabular}

Yukarıdaki tabloya baktığımızda ise görülüyor ki örneğimizdeki koşullarda blok zincir ağı, ödemenin başarısız olması durumunda en azından ödeme miktarını tazmin etmeyi kabul etmelidir. Bunu yaptıkları takdirde, ödeme miktarı ile komisyon ücretleri ve zaman kaybı esnasındaki olas1 döviz kuru dalgalanmasından kaynaklı kayıpların toplamı arasındaki kıyasa göre, blok zincir ağının tercih edilme durumu belirlenecektir. Eğer blok zincir ağındaki, ödeme kaybı olmasına rağmen katlanılacak toplam maliyet ve kayıplar, SWIFT ağındaki komisyon ücretinden daha düşük olursa $\left(M * 0,03+M * r_{B} \leq M * 0,071\right)$, ödemenin başarısız olma riskine rağmen, gönderici her durumda blok zincir ağını tercih edecektir. Eğer blok zincir ağında ödeme başarısız olduğunda katlanılacak toplam maliyetler, SWIFT ağının komisyon ücretinden fazla, ancak yine oradaki toplam maliyetlerden düşük olursa $\left(M * 0,071 \leq M * 0,03+M * r_{B} \leq M *\right.$ $0,071+M * r_{S}$ ) blok zincir ağının tercih edilmesi için bir koşul söz konusu olacaktır. Gönderici, blok zincir ağındaki ödemenin başarısız olması riski ile $(q)$ SWIFT ağında ödemenin aynı gün içerisinde gerçekleştirilememesi ihtimalini $\left(\mathrm{P}\left(t^{S}=1\right)=0,5\right)$ kıyaslayacaktır. Eğer blok zincir ağındaki başarısızlık riski, SWIFT ağındaki, ödemenin ertesi güne sarkma ihtimalinden düşük olursa $(q \leq 0,5)$ riske duyarsız göndericiler tarafindan blok zincir ağı tercih edilecektir. Blok zincir ağında ödemeler başarılı olursa aynı gün içerisinde tamamlanmaktadır. Dolayısıyla blok zincir ağının, sunduğu maliyet avantajını koruyarak, her durumda SWIFT'e tercih edilebilir olabilmesi için ödemenin başarılı olma ve aynı gün içerisinde tamamlanma ihtimalini SWIFT'ten daha yükseğe çıkarması $(0,5 \leq 1-q)$, ayrıca ödemenin başarısız olması durumunda da ödeme miktarını tazmin etmesi gerekmektedir.

Riskten sakınan (risk-averse) bir gönderici içinse, $\mathrm{C}_{\text {SWIFT }} \leq_{i c x} \mathrm{C}_{\text {BLOCк CHAIN }}$ durumunda SWIFT sistemi, tam tersi olması durumunda da blok zincir ağı ile gönderim yapılmalıdır. Bu kıyaslamanın yapılması için Teorem 1'deki koşullara bakıldığında $E\left[C_{S W I F T}\right]=E\left[C_{B L O C K}\right.$ CHAIN $]$ eşitliğinin sağlanması şartı 
Küresel Tedarik Zinciri ve Uluslararası Ticaret Yönetiminde Verimli Ödeme Sistemi Seçimi

görülmektedir. $\mathrm{Bu}$ ifade blok zincir ağındaki ödeme kaybı ihtimalinin net bir değere eşit olması koşulunu ortaya koymaktadır ki, sağlanması mümkün olmayabilir, yine Örnek 1'den gidecek olursak $\left(r_{B}, r_{S} \ll 1\right.$ olduğundan dolay1):

$E\left[C_{\text {SWIFT }}\right]=E\left[C_{\text {BLOCK CHAIN }}\right]$

$M * 0,071+0,5 * M * r_{S}=M * 0,03+q *\left(M+M * r_{B}\right)$

$q=\frac{0,071-0,03+0,5 * r_{S}}{1+r_{B}} \cong 0,041$.

Eğer örnekte riskten sakınan bir gönderici düşünülürse gözeteceği ölçütlerden birisi, döviz kurlarının yüksek dalgalanmalara maruz kalmadığı bir durumda SWIFT ve blok zincir ağlarının komisyon ücreti yüzdeleri arasındaki fark ile blok zincir ağındaki ödeme kaybının kıyaslamasıdır. Bu iki değer arasında yakınlık görülecek olursa iki sistemin ortaya koyduğu toplam maliyetlerle ilgili Teorem 1'de yer alan diğer koşula bakılmalıdır. Bu koşul ise farklı parametre grupları için farklı sonuçlar verebilir (örneğin farklı ödeme miktarlarına göre) ve bundan dolayı tüm parametrelerin net olduğu vaka özelinde çalışmada verilen denklemlerden yararlanarak tespit edilmesi gerekmektedir.

\section{Sonuç}

$\mathrm{Bu}$ çalışmada öncelikle uluslararası ticaret ve küresel tedarik zincirlerinde sınır-ötesi ödemeler için kullanılabilecek iki farklı ödeme sisteminden SWIFT ve blok zincir ağına dayalı ödeme sistemleri tanıtılmış, ilgili literatür ışığında farklılıkları ve birbirlerine göre avantaj ve dezavantajları açıklanmıştır. Günümüz küresel tedarik zincirlerinde yapılan uluslararası ödemelerde bu iki sistemden hangisinin kullanılacağı ile ilgili bir seçim yapılması, gerekli para akışının sağlanması için düzenli olarak verilmesi gereken bir kararı teşkil etmektedir. $\mathrm{Bu}$ kararın verilebilmesi için bir karar mekanizması oluşturulması, farklı koşullarda farklı kararların verilmesini gerektiren durumların gün 1şığına çıkarılması açısından önemlidir. Bu çalışmada ilgili karar mekanizmasının oluşturulması için matematiksel bir modele başvurulmuştur.

Modelde, bu iki ödeme sistemine ait dinamikler rassal değişkenler ve parametreler olarak belirtilmiş, karar mekanizmasının ortaya koyulması içinse iki ödeme sisteminin aynı ödeme için oluşturacağı maliyetlerin stokastik olarak kıyaslaması yapılmışıı. Blok zincir ağının SWIFT sistemine göre tercih edilebilirliğinin, blok zincir ile sınır-ötesi ödeme gönderiminde ödemenin başarısız olması ve bundan dolayı göndericinin ödeme miktarını kaybetmesi riski ile belirleyici bir ilişkisi bulunmaktadır. Blok zincir ağı ile sınır-ötesi ödemenin sunduğu ücret ve süre avantajına rağmen, SWIFT yerine blok zincir ödeme sisteminin tercih edilebilmesi için ödeme kaybı ihtimalinin ortadan kaldırılması veya en azından başarısız olan ödeme miktarının göndericiye iade edilmesi gerekmektedir. Bu iadenin sorumluluğunun kabul edildiği durumlarda ise, blok zincir ağının SWIFT'e göre maliyet avantajı korunarak, ödemenin blok zincir 
ağında başarısız olma ihtimali, SWIFT ağında ertesi güne sarkma ihtimalinden daha düşük hale getirilecek olursa riske duyarsız bir gönderici blok zincir ağını tercih edecektir. Riskten sakınan bir gönderici ise ilk olarak iki sistem arasındaki komisyon yüzdesi farkı ile blok zincir ağındaki ödeme kaybı olasılığını kıyaslayacaktır. Dolayısıyla blok zincir ağı ödeme sistemi yöneticilerinin ödemenin tüm aşamalarında, göndericinin kripto para cüzdanındaki işlemlerden alıcının hesabına varana kadar işlemlerin güvenliğini sağlaması ve hukuksal bir zorunluluk olmasa dahi bir aksaklıkta ödeme miktarını tazmin etmesi gerekmektedir.

Yazarların bilgisi dâhilinde SWIFT ve blok zincir ağlarının karşılaştırılmasına dair ilk matematiksel modelleme çabası olan bu çalışmayı takiben vaka çalışmaları ile modelin uyarlamasının yapılmasının ilerisi için literatüre katkısının olacağı düşünülmektedir.

\section{Kaynaklar}

Achanta, R. (2018), Cross-Border Money Transfer Using Blockchain-Enabled by Big Data, 5 Ocak 2020 tarihinde https://www.infosys.com/industries/ cards-and-payments/resources/Documents/cross-border-money-transfer. pdf adresinden alındi.

Ambrosia, D.W. (1980). New SWIFT Rules on The Liability of Financial İnstitutions for İnterest Losses Caused by Delay in İnternational Fund Transfers. Cornell International Law Journal, 13, 311-327.

Ba'tiz-Lazo, B. ve Wood, D. (2002). An historical Appraisal of İnformation Technology in Commercial Banking, Electronic Markets, 12, 192-205.

Bäuerle, N., \& Müller, A. (2006). Stochastic Orders and Risk Measures: Consistency and Bounds. Insurance: Mathematics and Economics, 38(1), 132-148.

Beck, R., Becker, C., Lindman, J., \& Rossi, M. (2017). Opportunities and risks of blockchain technologies (Dagstuhl Seminar 17132). Dagstuhl Reports, Schloss Dagstuhl-Leibniz-Zentrum fuer Informatik, 7(3), 99-142.

Casey, M., Crane, J., Gensler, G., Johnson, S., \& Narula, N. (2018). The Impact of Blockchain Technology on Finance: A Catalyst for Change. International Center for Monetary and Banking Studies. Geneva, Switzerland.

Cate, R. (2018, Mar). Ripple CEO at Money20/20 Asia: A New Payments System for the Digital Age 30 Ocak 2020 tarihinde

https://ripple.com/insights/ripple-ceo-money20-20-asia-new-payments-systemdigital-age/ adresinden alınd1.

Chartered Institute of Procurement \& Supply. (t.y.), 29 Aralık 2019 tarihinde https://www.cips.org/en-ME/knowledge/procurement-topics-andskills/srm-and-sc-management/global-supply-chains/ adresinden alındı. 
Küresel Tedarik Zinciri ve Uluslararası Ticaret Yönetiminde Verimli Ödeme Sistemi Seçimi

Cheng, J. ve Geva, B. (2016), Understanding Block Chain and Distributed Financial Technology: New Rails for Payments and an Analysis of Article 4A of the UCC. Business Law Today, 25(7) 1-4.

Chopra, S. ve Meindl, P. (2013), Supply Chain Management: Strategy, Planning, and Operation. Boston: Pearson.

Curkovic, S., Scannell, T., Wagner, B. ve Vitek, M. (2013), A Longitudinal Study of Supply Chain Risk Management Relative to COSO's Enterprise Risk Management Framework, Modern Management Science \& Engineering, 1(1), 13-36.

Demeyer, M. (2018), Blockchain Technology And Smart Contracts From A Financial Law Perspective, Doktora Tezi, Ghent Üniversitesi, Belçika. 5 Ocak 2020 tarihinde https://lib.ugent.be/fulltxt/RUG01/002/479 /332/RUG01-002479332_2018_0001_AC.pdf adresinden alınd1.

Deshpande, A., Stewart, K., Lepetit, L. ve Gunashekar, S. (2017), Distributed Ledger Technologies/Blockchain: Challenges, opportunities and the prospects for standards, 6 Ocak 2020 tarihinde https://www.bsigroup.com/LocalFiles/zh-tw/InfoSec-newsletter/ No2017 06/download/BSI_Blockchain DLT Web.pdf adresinden alındı.

Exalog-Payments \& treasury software. (t.y. a), SWIFT Network International Banking Communication Tool, 29 Aralık 2019 tarihinde http://www.exalog.com/en/swiftnet-network-banking-communication adresinden alınd.

Exalog-Payments \& Treasury Software. (t.y. b), SWIFT GPI and SEPA Instant Payment: How Will Companies Benefit? 29 Aralı 2019 tarihinde https://www.exalog.com/en/swift-gpi-and-sepa-instant-payment-howwill-companies-benefit adresinden alındı.

Guo, Y. ve Liang, C. (2016), Blockchain application and outlook in the banking industry, Financial Innovation, 2(24), 1-12.

Ishmaev, G. (2017), Blockchain Technology as an institution of Property, Metaphilosophy, 48(5), 666-686.

Ivannikov, N., Cvetkovic, R. ve Lilic., V. (2014), Innovations in International Payments, International Journal of Economics \& Law, (11), 45-50.

Karaca, O. (2005). Türkiye'de Faiz Oranı ile Döviz Kuru Arasındaki Ilişki: Faizlerin Düşürülmesi Kurları Yükseltir mi? (No. 2005/14). Discussion Paper. 30 Ocak tarihinde https://www.econstor.eu/bitstream/10419/ 83232/1/dp 2005-14.pdf adresinden alınd1.

Kozolchyk, B. (1992). The Paperless Letter of Credit and Related Documents of Title. Law and Contemporary Problems, 55, 31-101.

Manuj, I. ve Mentzer, J. T. (2008a), Global Supply Chain Risk Management, Journal of Business Logistics, 29(1), 133-155.

Manuj, I., ve Mentzer, J. T. (2008b), Global Supply Chain Risk Management Strategies, International Journal of Physical Distribution \& Logistics Management, 38(3), 192-223. 
Mohanty, D. (2019), Ripple \& Stablecoins, India: BPB Publications.

Morabito, V. (2017), Business Innovation Through Blockchain. Cham: Springer International Publishing.

Mosakheil, J. H. (2018), Security Threats Classification in Blockchains. 5 Ocak 2020 tarihinde https://repository.stcloudstate.edu/cgi/viewcontent.cgi? article $=1093 \&$ context $=$ msia etds adresinden alınd 1 .

Moslemi, A., Hilmola, O. P. ve Vilko, J. (2016), Risks in Emerging Markets: Logistics Services in the Mediterranean Region, Maritime Business Review, 1(3), 253-272.

Müller, A., \& Stoyan, D. (2002). Comparison Methods for Stochastic Models and Risks (Vol. 389). New York: Wiley.

Nakamoto, S. (2019), Bitcoin: A peer-to-peer electronic cash system. 29 Aralık 2019 tarihinde https:/git.dhimmel.com/bitcoin-whitepaper/ adresinden alınd.

Narayanan, A., Bonneau, J., Felten, E., Miller, A. ve Goldfeder, S. (2016), Bitcoin and Cryptocurrency Technologies: a Comprehensive Introduction, New Jersey: Princeton University Press.

Oh, J. ve Shong, I. (2017), A Case Study on Business Model İnnovations Using Blockchain: Focusing on Financial İnstitutions, Asia Pacific Journal of Innovation and Entrepreneurship, 11(3), 335-344.

Park, Y. S. (2007), Innovations in International Payment Systems and Their Implications for Banks, 29 Aralı 2019 tarihinde https://home.gwu.edu/ yspark/Files/5.pdf adresinden alındi.

Qiu, T., Zhang, R. ve Gao, Y. (2019), Ripple vs. SWIFT: Transforming Cross Border Remittance Using Blockchain Technology, Procedia Computer Science, 147, 428-434.

Ripple. (t. y.), 30 Ocak 2020 tarihinde https://ripple.com/xrp/adresinden alındı.

Rosner, M. T. ve Kang, A. (2015), Understanding and Regulating Twenty-First Century Payment Systems: The Ripple Case Study, Michigan Law Review, 114(649), 649-681.

Sarwar, S. (Feb, 2018). Ripple Looks Unstoppable - Both xCurrent and xRapid Lures Financial Sector. 30 Ocak 2020 tarihinde https://cryptocurrencynews.com/daily-news/ripple-news/ripple-looksunstoppable-xcurrent-xrapid/ adresinden alındi.

Scannell, T., Curkovic, S. ve Wagner, B. (2013), Integration of ISO 31000: 2009 and Supply Chain Risk Management, American Journal of Industrial and Business Management, 3(4), 367-377.

Scott S.V. ve Zachariadis, M. (2012), Origins and Development of SWIFT, London School of Economics, Business History, 54(3), 462-482.

Sivitska, Y. (2018). The influence of cryptocurrency on the future of the international financial payment system through the example of a bitcoin. 30 Ocak 2020 tarihinde 
Küresel Tedarik Zinciri ve Uluslararası Ticaret Yönetiminde Verimli Ödeme Sistemi Seçimi

http://srd.pgasa.dp.ua:8080/xmlui/bitstream/handle/123456789/836/Sivitska.pdf ?sequence $=1 \&$ is Allowed $=y$ adresinden alınd 1 .

Stiglitz, J. E., \& Rothschild, M. (1970). Increasing risk: I. A definition., Journal of Economic Theory, 2(3), 225-243.

Swan, M. (2018). Blockchain for Business: Next-Generation Enterprise Artificial İntelligence Systems. Advances in computers, 111, 121-162.

The World Bank. (2018, Mar). Remittance Prices Worldwide. 30 Ocak 2020 tarihinde https://remittanceprices.worldbank.org/sites/default/files/rpw report march2018.pdf adresinden alınd1.

Underwood, S. (2016), Blockchain Beyond Bitcoin, Communications of the $A C M, 59(11), 15-17$.

Vanetti, M. (2018). The Future of Cross-Boarder Payments. Yayımlanmamış Tez, Nova School of Business and Economics, Lisbon, Portekiz. 30 Ocak 2020 tarihinde

https://run.unl.pt/bitstream/10362/36376/1/Vanetti_2018.pdf adresinden alınd1.

Vennervirta, E. (2019). Blockchain and EU Trade Finance: Achieving Single Market Harmonisation Through Payment System Improvement. Yayımlanmamış Tez, Metropolia University of Applied Sciences, Finlandiya, 30 Ocak 2020 tarihinde

https://www.theseus.fi/bitstream/handle/10024/170482/Vennervirta_Erika.pdf?s equence $=2$ adresinden alınd.

Wu, B., ve Duan., T. (2019, March), The Application of Blockchain Technology in Financial markets, Journal of Physics: Conference Series (Vol. 1176, No. 042094). IOP Publishing.

Wu, T., ve Liang., X. (2017, August), Exploration and practice of inter-bank application based on blockchain, 2017 12th International Conference on Computer Science and Education (ICCSE) (pp. 219-224). IEEE.

Wüst, K., ve Gervais, A. (2018, Haziran), Do you need a Blockchain? 2018 Crypto Valley Conference on Blockchain Technology (CVCBT) (pp. 4554). IEEE. 